\title{
Synthesis and structure of mono-, bi- and trimetallic amine-bis(phenolate) cobalt(II) complexes $\uparrow$
}

\author{
Uttam K. Das, ${ }^{a}$ Julia Bobak, ${ }^{a}$ Candace Fowler, ${ }^{a}$ Sarah E. Hann, ${ }^{a}$ Chad F. Petten, ${ }^{a}$ Louise N. Dawe, ${ }^{b}$ \\ Andreas Decken, ${ }^{c}$ Francesca M. Kerton ${ }^{* a}$ and Christopher M. Kozak $* a$
}

\author{
Received 11th February 2010, Accepted 19th April 2010 \\ First published as an Advance Article on the web 17th May 2010 \\ DOI: 10.1039/c002843f
}

\begin{abstract}
A series of cobalt(II) amine-bis(phenolate) complexes has been prepared and characterized. The protonated tripodal tetradentate ligand precursors; dimethylaminoethylamino- $N, N$-bis(2methylene-4-tert-butyl-6-methylphenol), $\mathrm{H}_{2}\left[\mathrm{O}_{2} \mathrm{NN}^{\prime}\right]^{\text {BuMeNMe2 }}$, dimethylaminoethylamino- $N$, $N$-bis(2methylene-4,6-di-tert-butylphenol), $\mathrm{H}_{2}\left[\mathrm{O}_{2} \mathrm{NN}^{\prime}\right]^{\text {BuBunMe2 }}$, diethylaminoethylamino- $N, N$-bis(2methylene-4,6-di-tert-amylphenol), $\mathrm{H}_{2}\left[\mathrm{O}_{2} \mathrm{NN}^{\prime}\right]^{\text {AmAmNEt2 }}$ and 2-pyridylamino- $N$, $N$-bis(2-methylene4,6-di-tert-amylphenol), $\mathrm{H}_{2}\left[\mathrm{O}_{2} \mathrm{NN}^{\prime}\right]^{\text {AmAmPy}}$; were reacted with cobaltous acetate tetrahydrate under varying conditions to afford a range of monometallic, bimetallic and trimetallic species. An unusual four coordinate complex $\mathrm{Co}\left[\mathrm{O}_{2} \mathrm{NN}^{\prime}\right]^{\mathrm{AmAmNEt2}}$ containing $\mathrm{Co}^{\mathrm{II}}$ in a trigonal monopyramidal environment was structurally characterized, whereas using a less sterically demanding ligand a series of five coordinate complexes $\mathrm{Co}\left[\mathrm{O}_{2} \mathrm{NN}^{\prime}\right]^{\mathrm{BuBuNMe} 2}(\mathrm{~L})\left(\mathrm{L}=\mathrm{H}_{2} \mathrm{O}, \mathrm{CH}_{3} \mathrm{OH},\left(\mathrm{CH}_{3}\right)_{2} \mathrm{C}=\mathrm{O}\right.$, propylene oxide $)$ containing $\mathrm{Co}^{\mathrm{II}}$ in a trigonal bipyramidal environment was prepared. A new angular structural parameter related to $\tau$ is defined, where $\tau^{\prime}$ may be used to compare complexes with trigonal monopyramidal structures. In contrast, ligands containing a pendant pyridyl donor afford dimeric species including $\left\{\mathrm{Co}\left(\mu-\mathrm{CH}_{3} \mathrm{OH}\right)\left[\mathrm{O}_{2} \mathrm{NN}^{\prime}\right]^{\mathrm{AmAmPy}}\right\}_{2}$. In the absence of base and in the presence of excess cobaltous acetate, trimetallic complexes were isolated containing a central $\mathrm{Co}^{\mathrm{II}}$ in an octahedral environment coordinated to four $\mathrm{CH}_{3} \mathrm{OH}$ and two bridging acetate ligands between two $\mathrm{Co}\left[\mathrm{O}_{2} \mathrm{NN}^{\prime}\right]$ fragments with $\mathrm{Co}^{\mathrm{II}}$ in a trigonal bipyramidal setting. The paramagnetic $\mathrm{Co}^{\mathrm{II}}$ complexes reported were also characterized by UV-vis spectroscopy, mass spectrometry, cyclic voltammetry and magnetic measurements.
\end{abstract}

\section{Introduction}

The use of chelating tetradentate amine-bis(phenolate) ligands has recently played an increasingly important role in transition-metal catalyst design and modelling of metalloenzyme active-sites. They have been predominantly used with high-valent early transitionmetals where they have been employed as alternative auxiliary ligands to cyclopentadienyl-based systems. In combination with group 4 metals they display high activities towards olefin or cyclic ester polymerization. ${ }^{1-11}$ Also, group 3 and lanthanide metal complexes of these ligands have been effective as catalysts or initiators for ring-opening-polymerization of lactide and $\varepsilon$ caprolactone. ${ }^{12-22}$ By comparison, there has been limited use of amine-bis(phenolate) ligands with the mid-to-late first row

${ }^{a}$ Department of Chemistry, Memorial University of Newfoundland, St. John's, Newfoundland, Canada A1B 3X7. E-mail: fkerton@ mun.ca, ckozak@mun.ca; Fax:+1-709-737-3702

${ }^{b} C$-CART X-ray Diffraction Laboratory, Memorial University of Newfoundland, St. John's, Newfoundland, Canada A1B $3 X 7$

'Department of Chemistry, University of New Brunswick, Fredericton, New Brunswick, Canada E3B 5 A3

$\dagger$ Electronic supplementary information (ESI) available: Crystallographic data for $\mathbf{1}\left(\mathrm{CH}_{3} \mathrm{COCH}_{3}\right), \mathbf{1}\left(\mathrm{CH}_{3} \mathrm{OH}\right), \mathbf{1}\left(\mathrm{C}_{3} \mathrm{H}_{6} \mathrm{O}\right), \mathbf{1}\left(\mathrm{CH}_{3} \mathrm{OH}-\mathrm{H}_{2} \mathrm{O}\right) \mathbf{2}$, $\mathbf{3}\left(\mathrm{CH}_{3} \mathrm{OH}\right), \mathbf{4}, \mathbf{5}$ and $\mathbf{6}$ (cif format). Ball-and-stick model of $\mathbf{3}$, additional magnetic and electrochemical data (pdf). CCDC reference numbers 766019-766027. For ESI and crystallographic data in CIF or other electronic format see DOI: 10.1039/c002843f transition-metals. ${ }^{23-33}$ Some iron ${ }^{\mathrm{III}}$ complexes of this class of ligand have been investigated as a result of their close relationship to phenol-containing ligands found in non-heme iron containing metalloenzymes. ${ }^{34-43}$ We have recently reported novel iron ${ }^{\mathrm{III}}$ compounds bearing amine-bis(phenolate) ligands, which effectively catalyze the cross-coupling of aromatic Grignard reagents with alkyl halides possessing $\beta$-hydrogens. ${ }^{44}$ In terms of cobalt chemistry, a small number of bimetallic amine-bis(phenolate) complexes containing bridging phenolate groups have been structurally characterized and their magnetism investigated..$^{45-48}$

In addition to fundamental studies of their physical properties, cobalt coordination complexes also show interesting reactivity. For example, salen coordination compounds of $\mathrm{Co}^{\mathrm{II}}$ and $\mathrm{Co}^{\mathrm{III}}$ have been utilized as catalysts for coupling and copolymerization of carbon dioxide with epoxides, ${ }^{49-54}$ and homopolymerization of epoxides. ${ }^{55-57}$ Also, interesting stoichiometric oxidation chemistry using $\mathrm{Co}^{\mathrm{II}}$ salen complexes has been reported, ${ }^{58}$ and $\mathrm{Co}^{\mathrm{II}}$ phthalocyanine compounds are known to mediate catalytic aerobic oxidation of a range of organic substrates..$^{59,60}$

Herein we report the preparation, structure determination and properties of mono-, bi- and trimetallic cobalt complexes of the sterically hindered tetradentate tripodal ligands, $\left[\mathrm{O}_{2} \mathrm{NN}^{\prime}\right]^{\text {BuMeNMe2 }}$, $\left[\mathrm{O}_{2} \mathrm{NN}^{\prime}\right]^{\text {BuBuNMe2}},\left[\mathrm{O}_{2} \mathrm{NN}^{\prime}\right]^{\text {AmAmNEt2 }}$ and $\left[\mathrm{O}_{2} \mathrm{NN}^{\prime}\right]^{\text {AmAmPy }}$ (Fig. 1). These ligands contain two dialkyl-substituted phenol groups bearing either tert-butyl or tert-amyl (tert-pentyl) groups ortho to the hydroxyl group. They are prepared through a modified Mannich 


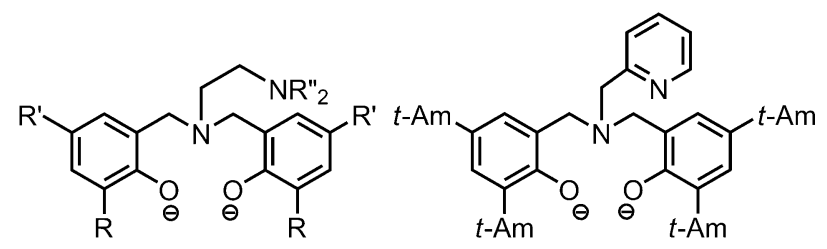

$\mathrm{R}=t-\mathrm{Bu}, \mathrm{R}^{\prime}=\mathrm{R}^{\prime \prime}=\mathrm{Me} ;\left[\mathrm{O}_{2} \mathrm{NN}^{\prime}\right]^{\text {BuMeNMe2 }} \quad\left[\mathrm{O}_{2} \mathrm{NN}^{\prime}\right]^{\text {AmAmPy }}$

$\mathrm{R}=\mathrm{R}^{\prime}=t-\mathrm{Bu}, \mathrm{R}^{\prime \prime}=\mathrm{Me} ;\left[\mathrm{O}_{2} \mathrm{NN}^{\prime}\right]^{\text {BuBuNMe2 }}$

$\mathrm{R}=\mathrm{R}^{\prime}=t-\mathrm{Am}, \mathrm{R}^{\prime \prime}=\mathrm{Et} ;\left[\mathrm{O}_{2} \mathrm{NN}^{\prime}\right]^{A m A m N E t 2}$

Fig. 1 Amine-bis(phenolate) ligands used in this study.

reaction between the respective disubstituted phenol, aqueous formaldehyde, and the respective $N, N$-dialkylethylenediamine or pyridylamine. Improved yields are obtained when these reactions are performed in water. ${ }^{61,62}$

\section{Experimental}

\section{General considerations}

Reactions were performed under an atmosphere of dry oxygenfree nitrogen by means of standard Schlenk techniques. However, some reactions (synthesis of $\mathbf{3}\left(\mathrm{CH}_{3} \mathrm{OH}\right)$ and 4-6) were worked up in air. Compounds $\mathbf{2}$ and $\mathbf{3}$ were isolated in an inert-atmosphere glove box (MBraun Labmaster). All solvents were purified using an MBraun Solvent Purification System, except methanol, which was distilled under nitrogen from $\mathrm{CaH}_{2}$. Reagents were purchased either from Aldrich or Alfa Aesar and used without further purification. $\mathrm{H}_{2}\left[\mathrm{O}_{2} \mathrm{NN}^{\prime}\right]^{\mathrm{BuMeNMe} 2}, \mathrm{H}_{2}\left[\mathrm{O}_{2} \mathrm{NN}^{\prime}\right]^{\text {BuBuNMe2}}, \mathrm{H}_{2}\left[\mathrm{O}_{2} \mathrm{NN}^{\prime}\right]^{\text {AmAmNEt2 }}$ and $\mathrm{H}_{2}\left[\mathrm{O}_{2} \mathrm{NN}^{\prime}\right]^{\mathrm{AmAmPy}}$ were prepared by modification of the literature methods, ${ }^{7,22,63,64}$ by using water instead of methanol as the reaction medium. ${ }^{61,62}$ MALDI-TOF MS was performed using an Applied Biosystems Voyager DE-PRO equipped with a reflectron, delayed ion extraction and high performance nitrogen laser (337 $\mathrm{nm})$. Anthracene was used as the matrix. ${ }^{65,66}$ AP-CI and ESI MS experiments were performed using the detector of an Agilent 1100 series LC/MSD. NMR spectra were recorded on a Bruker AVANCE $500 \mathrm{MHz}$ spectrometer. Variable temperature magnetic measurements were performed on powdered samples at $1000 \mathrm{G}$ using a Quantum Design MPMS-5S SQUID Magnetometer. The data were corrected for background and for the diamagnetism of all atoms. UV-Vis spectra were recorded on an Ocean Optics USB4000+ fiber optic spectrophotometer. Infrared spectra were recorded as $\mathrm{KBr}$ pellets on a Bruker Tensor 27 FT-IR spectrometer. Cyclic voltammetry measurements were performed on a Model HA 301 Hokuto Deuko Potentiostat/Galvanostat. Elemental analyses were performed at Canadian Microanalytical Service, Ltd. Delta, BC, Canada or Guelph Chemical Laboratories, Guelph, ON, Canada.

\section{Synthesis of metal complexes}

Synthesis of $1 . \quad \mathrm{H}_{2}\left[\mathrm{O}_{2} \mathrm{NN}^{\prime}\right]^{\text {BuBuNMe2 }}(2.00 \mathrm{~g}, 3.81 \mathrm{mmol})$, cobaltous acetate tetrahydrate $(0.95 \mathrm{~g}, 3.81 \mathrm{mmol})$ and $\mathrm{KOH}(0.53 \mathrm{~g}$, $9.45 \mathrm{mmol}$ ) were added under $\mathrm{N}_{2}$ to a Schlenk flask fitted with a condenser. A dry, degassed mixture of toluene $(25 \mathrm{~mL})$ and methanol $(25 \mathrm{~mL})$ was added to the solids. The resulting suspension was stirred and heated to reflux under $\mathrm{N}_{2}$ for $18 \mathrm{~h}$ to afford a dark purple solution. The solvent was removed in vacuo and the residue was extracted with toluene $(30 \mathrm{~mL})$. The mixture was filtered using a frit and the solvent was removed under vacuum. Washing the residue with pentane $(20 \mathrm{~mL})$ afforded 1 as an orange powder (yield: $1.79 \mathrm{~g}, 3.01 \mathrm{mmol}, \sim 79 \%$ ). Crystals suitable for X-ray diffraction were obtained from a number of solvents by slow cooling.

Cooling of a methanol solution of $\mathbf{1}$ at $-20{ }^{\circ} \mathrm{C}$ afforded pink crystals (yield: $\sim 26 \%$ ). The asymmetric unit in the solid state contained two $\mathrm{Co}^{\mathrm{II}}$ species, $\mathrm{Co}\left[\mathrm{O}_{2} \mathrm{NN}^{\prime}\right]^{\text {BuBunMe2 }}\left(\mathrm{H}_{2} \mathrm{O}\right)$ and $\mathrm{Co}\left[\mathrm{O}_{2} \mathrm{NN}^{\prime}\right]^{\mathrm{BuBuNMe} 2}\left(\mathrm{CH}_{3} \mathrm{OH}\right)$, and three methanol solvent molecules of recrystallization. Cooling of a methanol solution of $\mathbf{1}$, prepared using dry methanol, at $-20^{\circ} \mathrm{C}$ also afforded pink crystals. In the asymmetric unit, there were two five-coordinate cobalt ${ }^{\mathrm{II}}$ methanol adducts, $\left[\mathbf{1}\left(\mathrm{CH}_{3} \mathrm{OH}\right)\right]$, along with three methanol solvent molecules of recrystallization. Storage of a concentrated acetone solution of 1 at $-20{ }^{\circ} \mathrm{C}$ afforded dark pink crystals (yield: $45 \%$ ). In the asymmetric unit, there were two five coordinate cobalt ${ }^{\mathrm{II}}$ acetone adducts along with two acetone solvent molecules of recrystallization, $\left[\mathbf{1}\left(\mathrm{CH}_{3} \mathrm{COCH}_{3}\right)\right]$. Pink crystals of a propylene oxide adduct, $\left[\mathbf{1}\left(\mathrm{C}_{3} \mathrm{H}_{6} \mathrm{O}\right)\right]$, were obtained by slow cooling of a concentrated propylene oxide solution of $\mathbf{1}$ at $-35^{\circ} \mathrm{C}$ (yield: $\sim 51 \%$ ). In the asymmetric unit, there were two five-coordinate cobalt(II)-propylene oxide adducts and one propylene oxide solvent molecule.

Characterization of 1. Anal. Calcd for $\mathrm{C}_{34} \mathrm{H}_{54} \mathrm{CoN}_{2} \mathrm{O}_{2} ; \mathrm{C}$, 70.20; H, 9.36; N, 4.82. Found: C, 69.95; H, 9.34; N, 4.77. MALDI-TOF MS (positive mode, anthracene) $\mathrm{m} / \mathrm{z}=581$ $\left(\left[\mathrm{Co}\left[\mathrm{O}_{2} \mathrm{NN}^{\prime}\right]^{\mathrm{BuBuNMe} 2}\right]^{+}\right)$.

Characterization of $\mathbf{1}\left(\mathrm{CH}_{3} \mathrm{OH}\right)$. Anal. Calcd for $\mathrm{C}_{34} \mathrm{H}_{54} \mathrm{CoN}_{2} \mathrm{O}_{2}\left(2 \mathrm{CH}_{3} \mathrm{OH}\right) ; \mathrm{C}, 66.95 ; \mathrm{H}, 9.68 ; \mathrm{N}, 4.34$. Found: C, 67.11; H, 9.79; N, 4.49. IR (KBr, cm $\left.{ }^{-1}\right): 668(w), 740(\mathrm{~m})$, 779(m), 805(w), 830(m), 877(m), 912(w), 934(w), 997(w), 1036(w), 1087(w), 1108(m), 1132(w), 1165(m), 1202(w), 1237(s), 1271(s), 1302(s), 1361(m), 1412(m), 1437(s), 1465(s), 1602(w), 1770(w), 2859(w), 2900(w), 2950(m), 3368(br). UV-vis $\left(\mathrm{CH}_{2} \mathrm{Cl}_{2}\right) \lambda_{\max }, \mathrm{nm}$ (ع): 241 (20020), 295 (15000), 373 (2000), 470 (145), 553 (154), 655 (154); $\mu_{\text {eff }}\left(\mathrm{CDCl}_{3}, 298 \mathrm{~K}\right)=4.2 \mu_{\mathrm{B}}$. MALDI-TOF MS (positive mode, anthracene $) ; m / z=581\left(\left[\mathrm{Co}\left[\mathrm{O}_{2} \mathrm{NN}^{\prime}\right]^{\mathrm{BuBuNMe}}\right]^{+}\right)$.

Characterization of $\mathbf{1}\left(\mathrm{CH}_{3} \mathbf{C O C H}_{3}\right)$. Anal. Calcd for $\mathrm{C}_{37} \mathrm{H}_{60} \mathrm{CoN}_{2} \mathrm{O}_{3} ; \mathrm{C}, 69.46 ; \mathrm{H}, 9.45 ; \mathrm{N}, 4.38$. Found: C, 69.05; H, 9.38; N, 4.53. UV-vis $\left(\mathrm{CH}_{2} \mathrm{Cl}_{2}\right) \lambda_{\max }, \mathrm{nm}(\varepsilon): 241$ (22700), 297 (15600), 374 (2000), 472 (120), 553 (177), 655 (178); $\mu_{\text {eff }}\left(\mathrm{CDCl}_{3}\right.$, $298 \mathrm{~K})=4.4 \mu_{\mathrm{B}}$. MALDI-TOF MS (positive mode, anthracene); $m / z=581\left(\left[\mathrm{Co}\left[\mathrm{O}_{2} \mathrm{NN}^{\prime}\right]^{\mathrm{BuBuNMe} 2}\right]^{+}\right)$.

Characterization of $\mathbf{1}\left(\mathbf{C}_{3} \mathbf{H}_{6} \mathbf{O}\right)$. Anal. Calcd for $\mathrm{C}_{37} \mathrm{H}_{60} \mathrm{CoN}_{2} \mathrm{O}_{3} ; \mathrm{C}, 69.46 ; \mathrm{H}, 9.45 ; \mathrm{N}, 4.38$. Found: C, 69.98; $\mathrm{H}, 9.52 ; \mathrm{N}, 4.43$. IR $\left(\mathrm{KBr}, \mathrm{cm}^{-1}\right): 740(\mathrm{~m}), 781(\mathrm{~m}), 806(\mathrm{w})$, 824(s), 878(m), 912(w), 939(w), 1021(w), 1044(w), 1111(w), 1166(w), 1202(w), 1250(m), 1279(s), 1304(s), 1369(m), 1412(m), 1440(s), 1467(vs), 1602(w), 2865(w), 2901(w), 2952(m), 3386(br). $\mu_{\text {eff }}\left(\mathrm{CDCl}_{3}, 298 \mathrm{~K}\right)=4.2 \mu_{\mathrm{B}}$. AP-CI MS (positive mode, $\left.\mathrm{CHCl}_{3}\right) ; m / z=642\left(\left[\mathrm{Co}\left[\mathrm{O}_{2} \mathrm{NN}^{\prime}\right]^{\text {BuBuNMe} 2}\left(\mathrm{C}_{3} \mathrm{H}_{6} \mathrm{O}\right)+2 \mathrm{H}\right]^{+}\right) ; 605$ $\left(\left[\mathrm{Co}\left[\mathrm{O}_{2} \mathrm{NN}^{\prime}\right]^{\mathrm{BuBuNMe} 2}+\mathrm{Na}\right]^{+}\right) ; 582\left(\left[\mathrm{Co}\left[\mathrm{O}_{2} \mathrm{NN}^{\prime}\right]^{\mathrm{BuBuNMe} 2}+\mathrm{H}\right]^{+}\right)$.

Synthesis of 2. $\mathrm{H}_{2}\left[\mathrm{O}_{2} \mathrm{NN}^{\prime}\right]^{\text {AmAmNEt2 }}(6.09 \mathrm{~g}, 10.0 \mathrm{mmol})$ and cobaltous acetate tetrahydrate $(3.73 \mathrm{~g}, 15.0 \mathrm{mmol})$ were added to a Schlenk flask under $\mathrm{N}_{2}$. A dry, degassed mixture of toluene 
$(100 \mathrm{~mL})$ and methanol $(100 \mathrm{~mL})$ was added to the solids. $\mathrm{KOH}$ $(1.40 \mathrm{~g}, 25.0 \mathrm{mmol})$ was added under a flow of $\mathrm{N}_{2}$ to the flask. The resulting deep purple solution was stirred at room temperature for $3 \mathrm{~h}$. The solvent was removed in vacuo and the residue was washed with pentane $(2 \times 30 \mathrm{~mL})$. The remaining solid was extracted with methanol $(2 \times 50 \mathrm{~mL})$ and afforded 2 as microcrystalline brown crystals (yield: $4.99 \mathrm{~g}, \sim 75 \%$ ). Green-brown crystals of $\mathbf{2}$ suitable for X-ray diffraction analysis were grown by slow evaporation of a saturated toluene solution in a glovebox at $25^{\circ} \mathrm{C}$. (yield: $1.07 \mathrm{~g}$, $\sim 16 \%$ ).

Characterization of 2. Anal. Calcd for $\mathrm{C}_{40} \mathrm{H}_{66} \mathrm{CoN}_{2} \mathrm{O}_{2} ; \mathrm{C}$, 72.15; H, 9.99; N, 4.21. Found: C, 71.99; H, 9.69; N, 4.24. UV-vis $\left(\mathrm{CH}_{3} \mathrm{OH}\right) \lambda_{\max }, \mathrm{nm}(\varepsilon): 252$ (7500), 294 (7000), 304 (6400), $369 \mathrm{sh}$ (1500), $482(660) ; \mu_{\mathrm{eff}}\left(\mathrm{CDCl}_{3}, 298 \mathrm{~K}\right)=3.9 \mu_{\mathrm{B}}$. MALDI-TOF MS (positive mode, anthracene); $m / z=665\left(\left[\mathrm{Co}\left[\mathrm{O}_{2} \mathrm{NN}^{\prime}\right]^{\text {AmAmNEt2 }}\right]^{+}\right.$).

Synthesis of 3. $\mathrm{H}_{2}\left[\mathrm{O}_{2} \mathrm{NN}^{\prime}\right]^{\text {AmAmpy }}(2.28 \mathrm{~g}, 3.80 \mathrm{mmol})$, cobaltous acetate tetrahydrate $(0.96 \mathrm{~g}, 3.84 \mathrm{mmol})$ and $\mathrm{KOH}(0.54 \mathrm{~g}$, $9.60 \mathrm{mmol}$ ) were added under $\mathrm{N}_{2}$ to a Schlenk flask fitted with a condenser. A dry, degassed mixture of toluene $(25 \mathrm{~mL})$ and methanol $(25 \mathrm{~mL})$ was added to the mixture. The resulting mixture was stirred and heated to reflux under $\mathrm{N}_{2}$ for $24 \mathrm{~h}$ to afford an orange solution and purple solid. The solvent was removed in vacuo and the residue was extracted with toluene $(25 \mathrm{~mL})$. The mixture was filtered to give a dark brown solution. The solvent was removed under vacuum and the resulting solid washed with pentane $(20 \mathrm{~mL}$ ) to afford a yellow-brown powder, 3 (yield: $1.32 \mathrm{~g}$, $1.00 \mathrm{mmol}, \sim 53 \%$ ). Orange-red crystals of $\mathbf{3}$ were grown by slow cooling of a toluene solution at $-35^{\circ} \mathrm{C}$ in a glove box. Crystals of $3\left(\mathrm{CH}_{3} \mathrm{OH}\right)$ were grown by slow cooling of a saturated toluene$\mathrm{CH}_{3} \mathrm{OH}$ solution at $6{ }^{\circ} \mathrm{C}$.

Characterization of 3. Anal. Calcd for $\mathrm{C}_{40} \mathrm{H}_{58} \mathrm{CoN}_{2} \mathrm{O}_{2} ; \mathrm{C}$, 73.03; H, 8.89; N, 4.26. Found: C, 73.00; H, 8.89; N, 4.22. IR $\left(\mathrm{KBr}, \mathrm{cm}^{-1}\right)$ : 727(m), 760(m), 783(m), 819(w), 869(w), 906(w), 937(w), 971(w), 1015(w), 1054(w), 1130(w), 1157(w), 1215(w), 1252(m), 1301(s), 1358(w), 1378(w), 1413(w), 1435(s), 1464(vs), 1568(w), 1605(w), 2870(w), 2900(w), 2958(m). UV-vis $\left(\mathrm{CH}_{3} \mathrm{OH}\right)$ $\lambda_{\max }, \mathrm{nm}(\varepsilon): 272$ (6500), 295 (7000), 303 (6100), $385 \mathrm{sh}(870), 475$ (330). $\mu_{\text {eff }}\left(\mathrm{CDCl}_{3}, 298 \mathrm{~K}\right)=4.0 \mu_{\mathrm{B}}, \mu_{\text {eff }}($ solid, $300 \mathrm{~K})=4.9 \mu_{\mathrm{B}}$ (per Co). MALDI-TOF MS (positive mode, anthracene); $\mathrm{m} / \mathrm{z}=$ $1315\left(\left[\left\{\mathrm{Co}\left[\mathrm{O}_{2} \mathrm{NN}^{\prime}\right]^{\mathrm{AmAmPy}}\right\}_{2}\right]^{+}\right) ; 657\left(\left[\mathrm{Co}\left[\mathrm{O}_{2} \mathrm{NN}^{\prime}\right]^{\mathrm{AmAmPy}}\right]^{+}\right)$.

Characterization of $\mathbf{3}\left(\mathrm{CH}_{3} \mathrm{OH}\right)$. Anal. Calcd for $\mathrm{C}_{40} \mathrm{H}_{58} \mathrm{CoN}_{2} \mathrm{O}_{2}\left(2 \mathrm{CH}_{3} \mathrm{OH}\right)\left(\mathrm{H}_{2} \mathrm{O}\right) ; \mathrm{C}, 68.18 ; \mathrm{H}, 9.26 ; \mathrm{N}, 3.79$. Found: C, 68.29; $\mathrm{H}, 8.52 ; \mathrm{N}, 3.85$. IR ( $\mathrm{KBr}, \mathrm{cm}^{-1}$ selected peak): $3324(\mathrm{br}) v(\mathrm{O}-\mathrm{H})$ of methanol. UV-vis $\left(\mathrm{CH}_{3} \mathrm{OH}\right) \lambda_{\max }, \mathrm{nm}(\varepsilon): 268$ (6500), 294 (5900), 307 (5450), $390 \mathrm{sh}$ (980), 478 (240). $\mu_{\text {eff }}$ (solid, $300 \mathrm{~K})=1.7 \mu_{\mathrm{B}}$ (per Co). MALDI-TOF MS (positive mode, anthracene); $m / z=657\left(\left[\mathrm{Co}\left[\mathrm{O}_{2} \mathrm{NN}^{\prime}\right]^{\mathrm{AmAmPy}}\right]^{+}\right)$.

General procedure for the synthesis of trimetallic complexes, 46. $\mathrm{H}_{2}\left[\mathrm{O}_{2} \mathrm{NN}^{\prime}\right](4.40 \mathrm{mmol})$ and cobaltous acetate tetrahydrate $(1.30 \mathrm{~g}, 5.22 \mathrm{mmol})$ were placed under $\mathrm{N}_{2}$ in a Schlenk flask fitted with a condenser. A dry, degassed mixture of toluene $(50 \mathrm{~mL})$ and methanol $(50 \mathrm{~mL})$ was added to the mixture. The resulting suspension was stirred and heated to reflux under $\mathrm{N}_{2}$ for $24 \mathrm{~h}$ to afford a pale pink solution and a pale purple solid. The solid was collected on a frit and dissolved in hot chloroform $(25-50 \mathrm{~mL})$ to give a purple solution. Room temperature methanol was added dropwise to the hot, saturated chloroform solution until evidence of precipitation was seen. A few drops of chloroform were added to the purple solution to ensure complete dissolution of the solid. Crystals were obtained by cooling these solutions to $-20^{\circ} \mathrm{C}$. Pink to purple crystals were isolated in yields of $1.53 \mathrm{~g}(70 \%)$ for $\mathbf{4}$, $1.28 \mathrm{~g}(50 \%)$ for 5 , and $1.14 \mathrm{~g} \mathrm{(40 \% )}$ for $\mathbf{6}$.

Characterization of 4. Anal. Calcd for $\mathrm{C}_{62} \mathrm{H}_{100} \mathrm{Co}_{4} \mathrm{~N}_{3} \mathrm{O}_{12}$; $\mathrm{C}, 59.28 ; \mathrm{H}, 8.02 ; \mathrm{N}, 3.34$. Found: $\mathrm{C}, 59.48 ; \mathrm{H}, 8.05 ; \mathrm{N}$, 3.40. UV-vis $\left(\mathrm{CH}_{2} \mathrm{Cl}_{2}\right) \lambda_{\max }, \mathrm{nm}(\varepsilon): 250$ (43000), 300 (30000), 380 (3800), 535sh (700), 640 (300); $\mu_{\text {eff }}($ solid, $300 \mathrm{~K})=$ $4.73 \mu_{\mathrm{B}}$ (per Co) MALDI-TOF MS (positive mode, anthracene) $m / z=674\left(\left[\mathrm{Co}\left[\mathrm{O}_{2} \mathrm{NN}^{\prime}\right]^{\mathrm{BuMeNMe} 2} \mathrm{Co}(\mathrm{OAc})_{2}\right]^{+}\right), m / z=497$ $\left(\left[\mathrm{Co}\left[\mathrm{O}_{2} \mathrm{NN}^{\prime}\right]^{\text {BuMeNMe2 }}\right)\right.$.

Characterization of 5. Anal. Calcd for $\mathrm{C}_{76} \mathrm{H}_{130} \mathrm{Co}_{3} \mathrm{~N}_{4} \mathrm{O}_{12}$; $\mathrm{C}, 62.15 ; \mathrm{H}, 8.92 ; \mathrm{N}, 3.81$. Found: $\mathrm{C}, 62.13 ; \mathrm{H}, 8.35 ; \mathrm{N}$, 3.96. IR $\left(\mathrm{KBr}, \mathrm{cm}^{-1}\right)$ : 536(w), 586(w), 668(w), 740(w), 781(w), 806(w), 832(m), 878(m), 941(w), 1028(w), 1088(w), 1111(w), 1131(w), 1167(w), 1203(w), 1236(m), 1252(m), 1304(s), 1360(m), 1413(s), 1442(s), 1469(vs), 1576(vs), 2868(m), 2902(m), 2954(s), 3416(br). UV-vis $\left(\mathrm{CH}_{2} \mathrm{Cl}_{2}\right) \lambda_{\max }, \mathrm{nm}(\varepsilon): 245$ (44000), 295 (30800), 380 (4000), 528sh (700), 635 (320); $\mu_{\text {eff }}$ (solid, 300 $\mathrm{K})=4.67 \mu_{\mathrm{B}}$ (per Co) MALDI-TOF MS (positive mode, anthracene) $m / z=758\left(\left[\mathrm{Co}_{2}\left[\mathrm{O}_{2} \mathrm{NN}^{\prime}\right]^{\mathrm{BuBuNMe}} 2 \mathrm{Co}(\mathrm{OAc})_{2}\right]^{+}\right), m / z=$ $581\left(\left[\mathrm{Co}\left[\mathrm{O}_{2} \mathrm{NN}^{\prime}\right]^{\text {BuBunMe}}\right]^{+}\right)$.

Characterization of 6. Anal. Calcd for $\mathrm{C}_{88} \mathrm{H}_{154} \mathrm{Co}_{3} \mathrm{~N}_{4} \mathrm{O}_{12} ; \mathrm{C}$, 64.57; H, 9.48; N, 3.42. Found: C, 64.75; H, 9.70; N, 3.73. UV-vis $\left(\mathrm{CH}_{2} \mathrm{Cl}_{2}\right) \lambda_{\max }, \mathrm{nm}(\varepsilon)$ : 245 (44000), 295 (30000), 380 (4000), 528sh (700), 635 (320); MALDI-TOF MS (positive mode, anthracene) $m / z=783\left(\left[\mathrm{Co}\left[\mathrm{O}_{2} \mathrm{NN}^{\prime}\right]^{\mathrm{AmAmNE} 2} \mathrm{Co}(\mathrm{OAc})\right]^{+}\right), m / z=$ $665\left(\left[\mathrm{Co}\left[\mathrm{O}_{2} \mathrm{NN}^{\prime}\right]^{\mathrm{AmAmNE2}}\right]^{+}\right)$.

\section{Crystal structure determination}

Single crystals of suitable dimensions were used for data collection. Methods of crystal growth are outlined in the synthetic procedures above. Crystallographic and structure refinement data are given in Table 1.

For 1, 3-6; crystals were mounted on a diffraction loop. Measurements were made on a Rigaku Saturn CCD area detector with Mo-K $\alpha$ radiation. Data were collected and processed using CrystalClear (Rigaku). ${ }^{67}$ For $\mathbf{1}\left(\mathrm{CH}_{3} \mathrm{COCH}_{3}\right), \mathbf{1}\left(\mathrm{CH}_{3} \mathrm{OH}\right)$ [excluding alcoholic protons, $\mathrm{H}(109,113,117,121,125,129$, 133), that were introduced in difference map positions], and $\mathbf{1}\left(\mathrm{C}_{3} \mathrm{H}_{6} \mathrm{O}\right)$ hydrogen atoms were introduced in calculated positions with isotropic thermal parameters set twenty percent greater than those of their bonding partners. For 5, H(61) and $\mathrm{H}(65)$ were introduced in their difference map positions and allowed to refine positionally, with fixed isotropic thermal parameters (1.2 times greater than their bonding partners at the time they were introduced) and all other hydrogen atoms were introduced in calculated positions with isotropic thermal parameters set twenty percent greater than those of their bonding partners. For $\mathbf{6}$, alcoholic protons $[\mathrm{H}(73,77)]$ were introduced in difference map positions while all other hydrogens were introduced in calculated positions with isotropic thermal parameters set twenty percent greater than those of their bonding partners. In all cases, hydrogen atoms were refined on the riding model. For $\mathbf{1}\left(\mathrm{CH}_{3} \mathrm{COCH}_{3}\right)$, $\mathbf{1}\left(\mathrm{CH}_{3} \mathrm{OH}\right), \mathbf{1}\left(\mathrm{C}_{3} \mathrm{H}_{6} \mathrm{O}\right), \mathbf{3}\left(\mathrm{CH}_{3} \mathrm{OH}\right), \mathbf{5}, \mathbf{6}$ all non-hydrogen atoms 
Table 1 Crystallographic and structure refinement data for compounds $\mathbf{1}$ to $\mathbf{6}$

\begin{tabular}{|c|c|c|c|c|c|c|c|c|}
\hline Compound & $\mathbf{1}\left(\mathrm{CH}_{3} \mathrm{COCH}_{3}\right)$ & $\mathbf{1}\left(\mathrm{CH}_{3} \mathrm{OH}\right)$ & $\mathbf{1}\left(\mathrm{C}_{3} \mathrm{H}_{6} \mathrm{O}\right)$ & 2 & $3\left(\mathrm{CH}_{3} \mathrm{OH}\right)$ & 4 & 5 & 6 \\
\hline Chemical & $\mathrm{C}_{39.25} \mathrm{H}_{64.50}$ & $\mathrm{C}_{37.50} \mathrm{H}_{68} \mathrm{Co}$ & $\mathrm{C}_{37.75} \mathrm{H}_{61.50} \mathrm{Co}$ & $\mathrm{C}_{40} \mathrm{H}_{66} \mathrm{CoN}_{2} \mathrm{O}_{2}$ & $\mathrm{C}_{103} \mathrm{H}_{148} \mathrm{Co}_{2}$ & $\mathrm{C}_{64} \mathrm{H}_{106.8} \mathrm{Co}_{3}$ & $\mathrm{C}_{90} \mathrm{H}_{146} \mathrm{Co}_{3}$ & $\mathrm{C}_{88} \mathrm{H}_{154} \mathrm{Co}_{3}$ \\
\hline formula & $\mathrm{CoN}_{2} \mathrm{O}_{3.75}$ & $\mathrm{~N}_{2} \mathrm{O}_{5.50}$ & $\mathrm{~N}_{2} \mathrm{O}_{3.25}$ & & $\mathrm{~N}_{4} \mathrm{O}_{6}$ & $\mathrm{~N}_{4} \mathrm{O}_{12.4}$ & $\mathrm{~N}_{4} \mathrm{O}_{12}$ & $\mathrm{~N}_{4} \mathrm{O}_{12}$ \\
\hline Formula weight & 683.39 & 693.89 & 654.35 & 665.88 & 1656.19 & 1307.57 & 1652.96 & 1637.00 \\
\hline$T / \mathrm{K}$ & $123(2)$ & $123(2)$ & $153(2)$ & 198(1) & $153(2)$ & $138(2)$ & $123(2)$ & $128(2)$ \\
\hline Color, habit & $\begin{array}{l}\text { Dark pink, } \\
\text { irregular }\end{array}$ & Pink, irregular & Pink, irregular & Green, block & Black, chunk & $\begin{array}{l}\text { Purple, } \\
\text { irregular }\end{array}$ & Pink, prism & $\begin{array}{l}\text { Light purple, } \\
\text { prism }\end{array}$ \\
\hline Crystal & $0.20 \times 0.19 \times$ & $0.24 \times 0.14 \times$ & $0.26 \times 0.23 \times$ & $0.55 \times 0.40 \times$ & $0.52 \times 0.31 \times$ & $0.40 \times 0.69 \times$ & $0.18 \times 0.17 \times$ & $0.12 \times 0.11 \times$ \\
\hline Dimensions/mm & 0.18 & 0.09 & 0.21 & 0.30 & 0.25 & 0.68 & 0.17 & 0.06 \\
\hline Crystal system & Orthorhombic & Triclinic & Orthorhombic & Monoclinic & Triclinic & Monoclinic & Monoclinic & Monoclinic \\
\hline Space group & $P n a 2_{1}(\# 33)$ & $P \overline{1}(\# 2)$ & $P n a 2_{1}(\# 33)$ & $P 2_{1} / c(\# 14)$ & $P \overline{1}(\# 2)$ & $P 2_{1} / n(\# 14)$ & $P 2_{1} / c(\# 14)$ & $P 2_{1} / c(\# 14)$ \\
\hline$a / \AA$ & $23.579(3)$ & $14.902(2)$ & $23.496(3)$ & $10.833(2)$ & $10.346(3)$ & $9.7690(9)$ & $11.027(3)$ & $12.862(2)$ \\
\hline$b / \AA$ & $23.671(3)$ & $15.3466(15)$ & $23.319(3)$ & $30.704(7)$ & $15.283(5)$ & $17.4799(17)$ & $22.278(5)$ & $22.109(3)$ \\
\hline$c / \AA$ & $14.476(2)$ & $19.850(3)$ & 14.4917(17) & $11.725(3)$ & $15.482(5)$ & $19.904(2)$ & $20.267(5)$ & $18.557(3)$ \\
\hline$\alpha\left(^{\circ}\right)$ & 90 & $74.869(10)$ & 90 & 90 & $100.085(3)$ & 90 & 90 & 90 \\
\hline$\beta\left({ }^{\circ}\right)$ & 90 & $89.538(13)$ & 90 & $92.829(4)$ & $97.893(3)$ & $90.771(2)$ & $113.692(6)$ & 119.714(3) \\
\hline$\gamma\left({ }^{\circ}\right)$ & 90 & $67.524(9)$ & 90 & 90 & $105.592(4)$ & 90 & 90 & 90 \\
\hline$V / \AA^{3}$ & $8079.7(20)$ & 4028.0(10) & 7940.3(16) & 3895.0(15) & 2277.1(13) & $3398.6(6)$ & 4559.3(20) & $4583.0(12)$ \\
\hline$Z$ & 8 & 4 & 8 & 4 & 1 & 2 & 2 & 2 \\
\hline$D_{\mathrm{c}} / \mathrm{g} \mathrm{cm}^{-3}$ & 1.124 & 1.144 & 1.095 & 1.136 & 1.208 & 1.278 & 1.204 & 1.186 \\
\hline$\mu(\mathrm{Mo}-\mathrm{K} \alpha) / \mathrm{cm}^{-1}$ & 4.62 & 4.67 & 4.66 & 7.1073 & 4.20 & 7.84 & 5.98 & 5.94 \\
\hline$F(000)$ & 2968 & 1512 & 2840 & 1452 & 896 & 1398 & 1782 & 1774 \\
\hline $\begin{array}{l}\theta \text { Range for } \\
\text { collection }\left({ }^{\circ}\right)\end{array}$ & 2.72 to 26.50 & 2.71 to 26.50 & 2.72 to 26.50 & 1.33 to 27.50 & 2.72 to 26.50 & 2.55 to 27.50 & 2.72 to 27.50 & 2.69 to 26.50 \\
\hline $\begin{array}{l}\text { Reflections } \\
\text { collected }\end{array}$ & 67575 & 35216 & 68663 & 15018 & 17963 & 30947 & 42832 & 40123 \\
\hline $\begin{array}{l}\text { Independent } \\
\text { reflections }\end{array}$ & 16357 & 16429 & 16419 & 8666 & 9168 & 7781 & 10466 & 9487 \\
\hline $\begin{array}{l}\text { Parameters/ } \\
\text { restraints }\end{array}$ & $848 / 1$ & $831 / 0$ & $848 / 1$ & $473 / 69$ & $425 / 0$ & $381 / 0$ & $500 / 0$ & $485 / 0$ \\
\hline$R$ (int) & 0.0623 & 0.0401 & 0.0492 & 0.0388 & 0.0250 & 0.0257 & 0.0442 & 0.0472 \\
\hline$R, \mathrm{w} R 2$ (all) & $0.0636,0.1680$ & $0.0810,0.1776$ & $0.0696,0.1824$ & $0.0715,0.1843$ & $0.0578,0.1794$ & $0.0490,0.1314$ & $0.0795,0.1996$ & $0.0705,0.1670$ \\
\hline $\begin{array}{l}R, \mathrm{w} R 2[I> \\
2 \sigma(I)]^{a}\end{array}$ & $0.0601,0.1632$ & $0.0697,0.1674$ & $0.0667,0.1792$ & $0.0588,0.1733$ & $0.0562,0.1762$ & $0.0468,0.1288$ & $0.0753,0.1953$ & $0.0651,0.1623$ \\
\hline GOF on $F^{2}$ & 1.068 & 1.094 & 1.101 & 1.040 & 1.104 & 1.058 & 1.076 & 1.116 \\
\hline
\end{tabular}

were refined anisotropically, however, for 4 some were refined isotropically. For $\mathbf{1}\left(\mathrm{CH}_{3} \mathrm{COCH}_{3}\right), \mathbf{1}\left(\mathrm{C}_{3} \mathrm{H}_{6} \mathrm{O}\right), \mathbf{3}\left(\mathrm{CH}_{3} \mathrm{OH}\right), \mathbf{4}, \mathbf{5}$, and 6 the structures were solved by direct methods, ${ }^{68}$ and for $\mathbf{1}\left(\mathrm{CH}_{3} \mathrm{OH}\right)$ by a Patterson orientation/translation search. ${ }^{69}$ The structures for $\mathbf{1}\left(\mathrm{CH}_{3} \mathrm{COCH}_{3}\right), \mathbf{1}\left(\mathrm{CH}_{3} \mathrm{OH}\right), \mathbf{1}\left(\mathrm{C}_{3} \mathrm{H}_{6} \mathrm{O}\right), \mathbf{3}\left(\mathrm{CH}_{3} \mathrm{OH}\right)$, 4, 5, 6 were expanded using Fourier techniques. ${ }^{70}$ For adducts of 1 and 3-6, the non-hydrogen atoms were refined anisotropically and hydrogen atoms were refined using the riding model.

For $\mathbf{1}\left(\mathrm{CH}_{3} \mathrm{COCH}_{3}\right), \mathbf{1}\left(\mathrm{CH}_{3} \mathrm{OH}\right)$ and $\mathbf{1}\left(\mathrm{C}_{3} \mathrm{H}_{6} \mathrm{O}\right)$, two cobalt complexes are present in the asymmetric unit. For $\mathbf{1}\left(\mathrm{CH}_{3} \mathrm{COCH}_{3}\right)$, 1.5 acetone molecules are present as lattice solvent in the asymmetric unit with $[\mathrm{C}(75-77)$ and $\mathrm{O}(7)]$ at a half-occupancy and $[\mathrm{C}(78-80)$ and $\mathrm{O}(8)]$ at full-occupancy. For $\mathbf{1}\left(\mathrm{CH}_{3} \mathrm{OH}\right)$, the $Z$ value was set to four in order to give the formula per monomer, $\left[\left(\mathrm{C}_{34} \mathrm{H}_{54} \mathrm{O}_{2} \mathrm{~N}_{2}\right) \mathrm{Co}\left(\mathrm{CH}_{3} \mathrm{OH}\right)\right]\left(\mathrm{CH}_{3} \mathrm{OH}\right)_{2.5}$, and 2.5 methanol molecules as lattice solvent. For $\mathbf{1}\left(\mathrm{C}_{3} \mathrm{H}_{6} \mathrm{O}\right)$, the $Z$ value was also set to four to give 0.25 propylene oxide $\left(\mathrm{C}_{3} \mathrm{H}_{6} \mathrm{O}\right)$ molecules as lattice solvent. Furthermore, for $\mathbf{1}\left(\mathrm{C}_{3} \mathrm{H}_{6} \mathrm{O}\right)$, there are two disordered moieties in the model. The first is a disordered $t$-butyl group consisting of [C(59-61)] and [C(62-64)], refined with PART commands, each part at $50 \%$ occupancy. The corresponding protons could not be located in difference map positions and were omitted from the model. The second area of disorder consists of [C(72), H(100-102)] at 75\% occupancy, and [C(75), H(103-105)] at $25 \%$ occupancy in a propylene oxide molecule, also refined with PART commands. The other three protons on this propylene oxide could not be located in difference map positions, and were omitted from the model. However, these protons are included in the formula unit for the structure. A fourth solvent adduct of 1 was also crystallographically characterized and contains both a methanol and water adduct in the crystallographic unit cell. Crystallographic data (cif format) for compound $\mathbf{1}\left(\mathrm{CH}_{3} \mathrm{OH}-\mathrm{H}_{2} \mathrm{O}\right)$ are available in the Electronic Supplementary Information. $\dagger$ For $3\left(\mathrm{CH}_{3} \mathrm{OH}\right)$, the Platon ${ }^{71}$ Squeeze procedure was applied to recover 154 electrons per unit cell in one void (total volume $624 \AA^{3}$ ); that is 154 electrons per formula unit (with $Z=1$ in this model). Disordered solvent lattice toluene molecules were present prior to the application of Squeeze, however, a satisfactory point atom model could not be achieved. The application of Squeeze gave a good improvement in the data statistics and allowed for a full anisotropic refinement of the structure. For 4, protons were located in the difference map and initially refined positionally with a fixed thermal parameter. In the final round of least squares these protons were refined on a riding model with isotropic thermal parameters set twenty percent greater than those of their bonding partners. The model contains one partial occupancy water molecule as lattice solvent; its corresponding hydrogen atoms could not be located in the difference map and hence were omitted from the model, as were the $\mathrm{OH}$ protons of the methanol molecules. For $\mathbf{5}$, one full occupancy toluene molecule is also present as lattice 


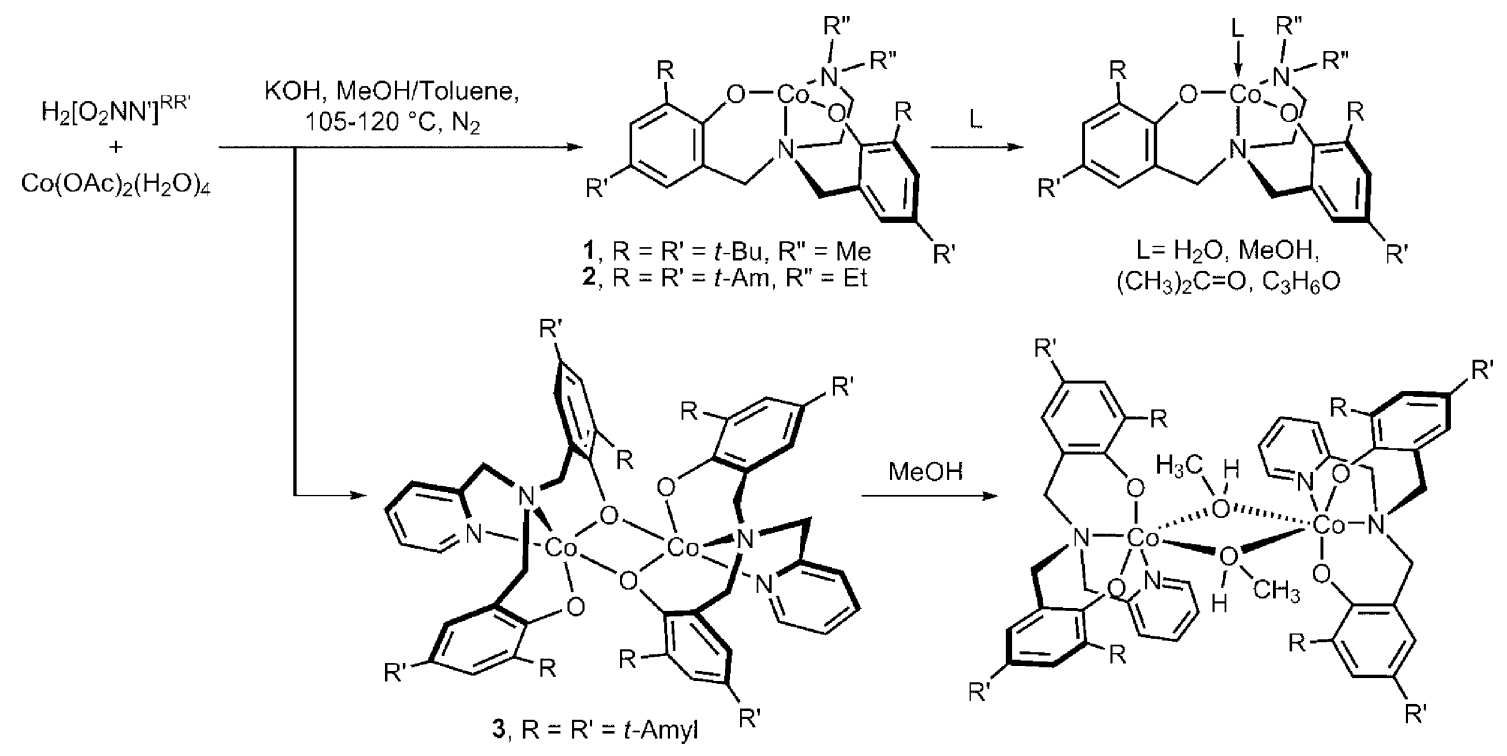

Scheme 1 Syntheses of mono- and bi-metallic amine-bis(phenolate) complexes of $\mathrm{Co}^{\mathrm{II}}$.

solvent in the asymmetric unit. For $\mathbf{6}$, the asymmetric unit contains half the $\mathrm{Co}_{3}{ }_{3}$ complex and so the $Z$ value was set to two in order to give the formula per complex.

For compounds 1, 3-6, neutral atom scattering factors were taken from Cromer and Waber. ${ }^{72}$ Anomalous dispersion effects were included in $F$ calc; ${ }^{73}$ the values for $\Delta \mathrm{f}^{\prime}$ and $\Delta \mathrm{f}^{\prime \prime}$ were those of Creagh and McAuley. ${ }^{74}$ The values for the mass attenuation coefficients are those of Creagh and Hubbell. ${ }^{75}$ All calculations were performed using the CrystalStructure, ${ }^{76,77}$ crystallographic software package except for refinement, which was performed using SHELXL-97.68

For 2, single crystals were coated with Paratone-N oil, mounted using a polyimide MicroMount and frozen in the cold nitrogen stream of the goniometer. A hemisphere of data was collected on a Bruker AXS P4/SMART 1000 diffractometer using $\omega$ and $\theta$ scans with a scan width of $0.3^{\circ}$ and $20 \mathrm{~s}$ exposure times. The detector distance was $5 \mathrm{~cm}$. The crystal was twinned and the orientation matrices for two components were determined (CELL_NOW) ${ }^{78}$ The data were reduced (SAINT) ${ }^{79}$ and corrected for absorption (TWINABS) ${ }^{80}$ The structure was solved by direct methods and refined by full-matrix least squares on $\mathrm{F}^{2}$ (SHELXTL) ${ }^{81,82}$ on all data. Two of the $t$-amyl groups were disordered and the site occupancy determined using an isotropic model as 0.40 $(\mathrm{C}(30)), 0.38\left(\mathrm{C}\left(30^{\prime}\right)\right), 0.22\left(\mathrm{C}\left(30^{\prime \prime}\right), 0.63(\mathrm{C}(37)-\mathrm{C}(40)\right.$, and 0.37 $\left(\mathrm{C}\left(37^{\prime}\right)-\mathrm{C}\left(40^{\prime}\right)\right)$ and fixed in subsequent refinement cycles. All non-hydrogen atoms were refined using anisotropic displacement parameters. Hydrogen atoms were included in calculated positions and refined using a riding model. Methyl and ethyl positions in the disordered side chains were superimposed and hydrogen atoms for the affected carbon atoms were omitted.

\section{Results and discussion}

\section{Syntheses and structures of monometallic complexes}

Reactions in a toluene-methanol mixture of approximately one equivalent of cobaltous acetate tetrahydrate with an equivalent of protio-ligand under basic conditions afforded dark purple mix- tures. Upon removal of the solvent under vacuum and subsequent extraction of the products using toluene, yellow-brown powders, 1-3, Scheme 1, were isolated in good to moderate yields. These powders have a formulation of $\mathrm{Co}^{\mathrm{II}}\left[\mathrm{O}_{2} \mathrm{NN}^{\prime}\right]$ when the pendant donor is dimethylamino- or diethylamino-, whereas they possess the formulation $\left\{\mathrm{Co}^{\mathrm{II}}\left[\mathrm{O}_{2} \mathrm{NN}^{\prime}\right]\right\}_{2}$ when the pendant donor is a pyridyl group (see below).

Recrystallizations of the monometallic species $\mathbf{1}$ have been performed in a range of solvents. In the presence of donor solvents, trigonal bipyramidal $\mathrm{Co}^{\mathrm{II}}$ complexes are obtained. The equatorial plane of each $\mathrm{Co}^{\mathrm{II}}$ ion consists of two phenolate oxygens, $\mathrm{O}(1)$ and $\mathrm{O}(2)$, and a dimethylamino donor, $\mathrm{N}(2)$. The nitrogen donor in the backbone of the ligand, $\mathrm{N}(1)$, occupies an apical position with the remaining coordination site taken up by the oxygen atom, $\mathrm{O}(5)$, of the donor solvent. Complexes have been structurally characterized containing acetone $\mathbf{1}\left(\mathrm{CH}_{3} \mathrm{COCH}_{3}\right)$, methanol $\mathbf{1}\left(\mathrm{CH}_{3} \mathrm{OH}\right)$, and propylene oxide $1\left(\mathrm{C}_{3} \mathrm{H}_{6} \mathrm{O}\right)$ in this position. Their structures are shown in Fig. 2 to 4 with bond lengths and angles given in Tables 2 to 4 . Each structure contains two $\mathrm{Co}^{\mathrm{II}}$ complexes in the asymmetric unit. A fourth complex of this class has also been structurally characterized and contains a 1:1 mixture of methanol and aquo solvent adducts. Bond lengths and angles for that version are similar to the methanol adduct and will not be discussed further. Crystallographic data for the mixed aquo and methanol adduct, $\mathbf{1}\left(\mathrm{CH}_{3} \mathrm{OH}-\mathrm{H}_{2} \mathrm{O}\right)$, are available in Electronic Supplementary Information. $\uparrow$ The distorted trigonal bipyramidal coordination environments of the $\mathrm{Co}^{\mathrm{II}}$ ions in $\mathbf{1}\left(\mathrm{CH}_{3} \mathrm{COCH}_{3}\right)$, $\mathbf{1}\left(\mathrm{CH}_{3} \mathrm{OH}\right)$ and $\mathbf{1}\left(\mathrm{C}_{3} \mathrm{H}_{6} \mathrm{O}\right)$ possess $\tau$ values of 0.72 and 0.78 , 0.66 and 0.80 , and 0.74 and 0.77 , respectively ${ }^{83}$ The significant differences in $\tau$ values between the two molecules of $\mathbf{1}\left(\mathrm{CH}_{3} \mathrm{OH}\right)$ are due to intermolecular hydrogen bonding between methanol solvent of crystallization and one molecule of $1\left(\mathrm{CH}_{3} \mathrm{OH}\right)$. The protic nature of the coordinated methanol also leads to a degree of asymmetry in the $\mathrm{Co}-\mathrm{O}_{\text {phenolate }}$ bond distances in the two molecules of $1\left(\mathrm{CH}_{3} \mathrm{OH}\right)$ in the structure. Each molecule contains a short Co-O bond (1.930(2) $\AA, 1.935(2) \AA)$ and a longer $\mathrm{Co}-\mathrm{O}$ bond $(1.972(2) \AA, 1.982(2) \AA)$. In $\mathbf{1}\left(\mathrm{CH}_{3} \mathrm{COCH}_{3}\right)$ and $\mathbf{1}\left(\mathrm{C}_{3} \mathrm{H}_{6} \mathrm{O}\right)$, this variation in $\mathrm{Co}-\mathrm{O}$ bond distances is not observed and bond 


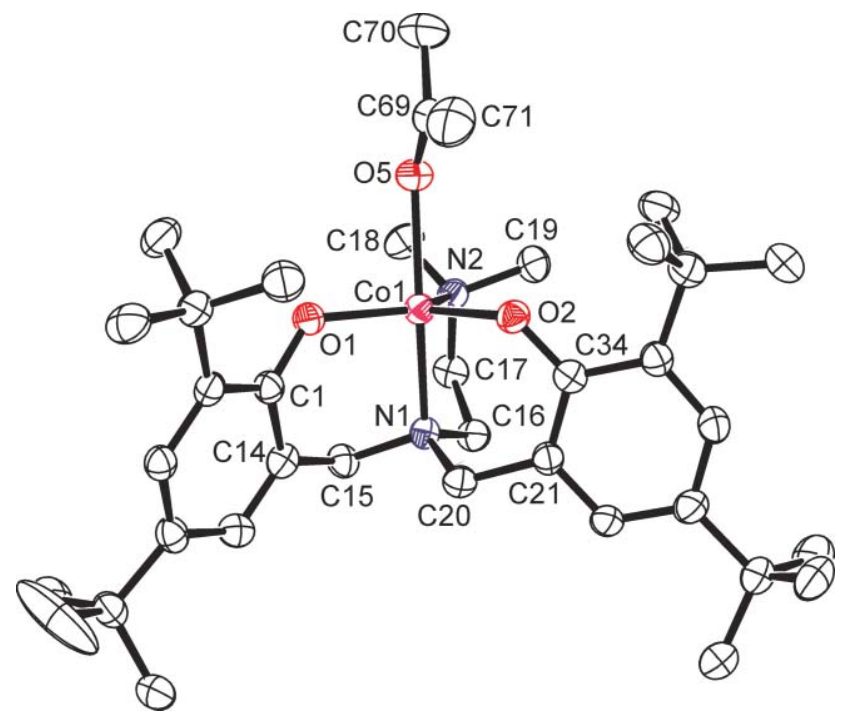

Fig. 2 ORTEP diagram of the molecular structure of the acetone adduct of 1 with $50 \%$ thermal ellipsoid probability. Only the molecule containing $\mathrm{Co}(1)$ is shown for clarity and solvent of crystallization omitted.

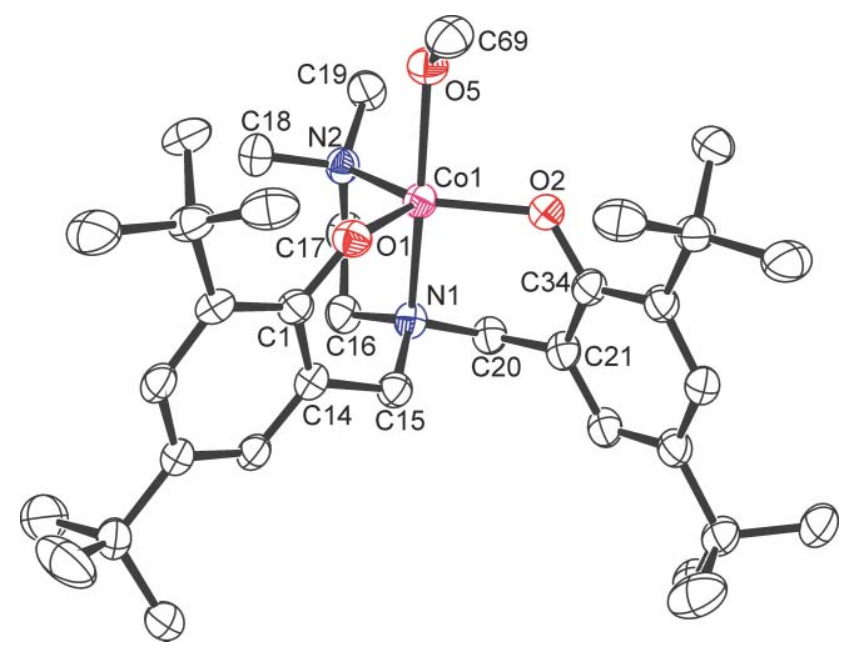

Fig. 3 ORTEP diagram of the molecular structure of the methanol adduct of $\mathbf{1}$ with $50 \%$ thermal ellipsoid probability. Only the molecule containing $\mathrm{Co}(1)$ shown for clarity and the solvent of crystallization omitted.

distances are in the range of 1.922(3) $\AA$ and 1.947(3) $\AA$. A survey ${ }^{84}$ of related $\mathrm{Co}^{\text {II }}$ structures shows that these $\mathrm{Co}-\mathrm{O}$ bond distances are typical, as the mean value for these is $1.945 \AA$ (standard deviation of $0.031 \AA){ }^{46,85-89}$ Furthermore, the tertiary amine N-Co bond distances are also similar to those previously reported (mean value of $2.144 \AA$, standard deviation of $0.053 \AA$ ) ${ }^{46,86,90-94}$

However, the cavity-like nature of these ligands, as has been observed with a range of metals, means that an additional ligand in the apical position can be varied with some degree of control by simply changing the solvent of recrystallization. Also, the bond distance between the $\mathrm{Co}^{\mathrm{II}}$ center and the apical donor appears to be related to the steric demands of this ligand, with the $\mathrm{Co}(1)-$ $\mathrm{O}(5)$ bond distance in $\mathbf{1}\left(\mathrm{C}_{3} \mathrm{H}_{6} \mathrm{O}\right)$ being the longest of the three and the shortest being in $\mathbf{1}\left(\mathrm{CH}_{3} \mathrm{OH}\right)$. Perhaps the most interesting of these three adducts is the propylene oxide complex, as $\mathrm{Co}^{\text {III }}$ complexes are known to catalyse reactions of epoxides and carbon

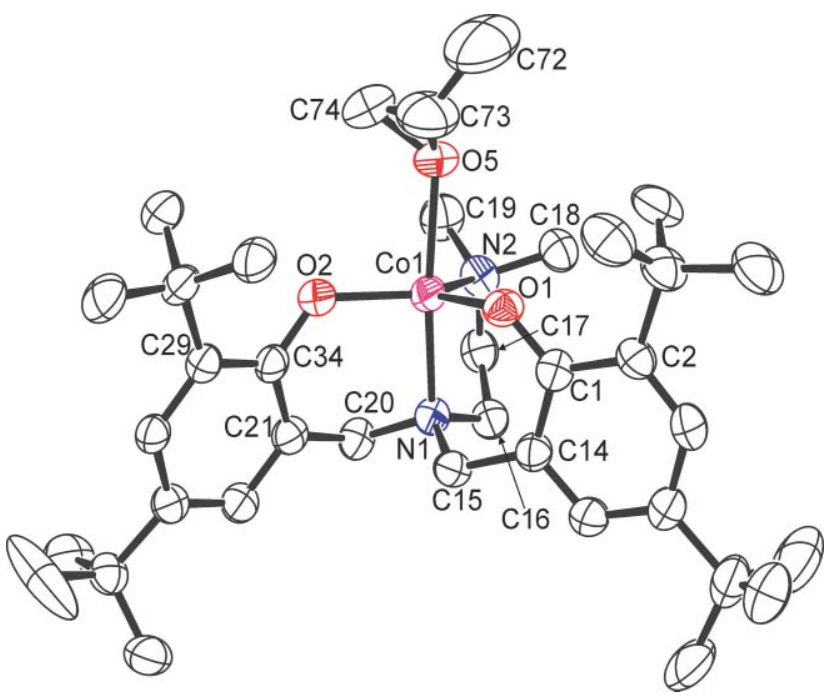

Fig. 4 ORTEP diagram of the molecular structure of the propylene oxide adduct of 1 with $50 \%$ thermal ellipsoid probability. Only the molecule containing $\mathrm{Co}(1)$ and $(R)$-isomer of propylene oxide are shown, and solvent of crystallization omitted.

Table 2 Selected bond lengths $[\AA]$ and angles $\left[{ }^{\circ}\right]$ for the acetone adduct of 1

\begin{tabular}{|c|c|c|c|}
\hline $\mathrm{Co}(1)-\mathrm{O}(1)$ & $1.923(3)$ & $\mathrm{N}(1)-\mathrm{Co}(1)-\mathrm{N}(2)$ & $82.79(11)$ \\
\hline $\mathrm{Co}(1)-\mathrm{O}(2)$ & $1.937(3)$ & $\mathrm{O}(1)-\mathrm{Co}(1)-\mathrm{O}(5)$ & $91.77(10)$ \\
\hline $\mathrm{Co}(1)-\mathrm{N}(1)$ & $2.135(3)$ & $\mathrm{O}(2)-\mathrm{Co}(1)-\mathrm{O}(5)$ & $93.62(10)$ \\
\hline $\mathrm{Co}(1)-\mathrm{N}(2)$ & $2.150(3)$ & $\mathrm{N}(1)-\mathrm{Co}(1)-\mathrm{O}(5)$ & $168.94(10)$ \\
\hline $\mathrm{Co}(1)-\mathrm{O}(5)$ & $2.208(2)$ & $\mathrm{N}(2)-\mathrm{Co}(1)-\mathrm{O}(5)$ & $86.49(11)$ \\
\hline $\mathrm{Co}(2)-\mathrm{O}(4)$ & $1.929(3)$ & $\mathrm{O}(4)-\mathrm{Co}(2)-\mathrm{O}(3)$ & $123.51(11)$ \\
\hline $\mathrm{Co}(2)-\mathrm{O}(3)$ & $1.947(3)$ & $\mathrm{O}(4)-\mathrm{Co}(2)-\mathrm{N}(4)$ & $116.22(12)$ \\
\hline $\mathrm{Co}(2)-\mathrm{N}(4)$ & $2.140(3)$ & $\mathrm{O}(3)-\mathrm{Co}(2)-\mathrm{N}(4)$ & $120.25(12)$ \\
\hline $\mathrm{Co}(2)-\mathrm{N}(3)$ & $2.151(3)$ & $\mathrm{O}(4)-\mathrm{Co}(2)-\mathrm{N}(3)$ & $91.91(10)$ \\
\hline $\mathrm{Co}(2)-\mathrm{O}(6)$ & $2.159(3)$ & $\mathrm{O}(3)-\mathrm{Co}(2)-\mathrm{N}(3)$ & $93.32(11)$ \\
\hline $\mathrm{O}(1)-\mathrm{C}(1)$ & $1.331(4)$ & $\mathrm{N}(4)-\mathrm{Co}(2)-\mathrm{N}(3)$ & $82.82(11)$ \\
\hline $\mathrm{O}(2)-\mathrm{C}(34)$ & $1.332(4)$ & $\mathrm{O}(4)-\mathrm{Co}(2)-\mathrm{O}(6)$ & $84.60(12)$ \\
\hline $\mathrm{O}(3)-\mathrm{C}(35)$ & $1.339(4)$ & $\mathrm{O}(3)-\mathrm{Co}(2)-\mathrm{O}(6)$ & $96.10(12)$ \\
\hline $\mathrm{O}(4)-\mathrm{C}(68)$ & $1.333(4)$ & $\mathrm{N}(4)-\mathrm{Co}(2)-\mathrm{O}(6)$ & $90.66(12)$ \\
\hline $\mathrm{O}(5)-\mathrm{C}(69)$ & $1.207(4)$ & $\mathrm{N}(3)-\mathrm{Co}(2)-\mathrm{O}(6)$ & $170.36(12)$ \\
\hline $\mathrm{O}(6)-\mathrm{C}(72)$ & $1.191(5)$ & $\mathrm{C}(1)-\mathrm{O}(1)-\mathrm{Co}(1)$ & $127.6(2)$ \\
\hline $\mathrm{O}(7)-\mathrm{C}(75)$ & $1.195(10)$ & $\mathrm{C}(34)-\mathrm{O}(2)-\mathrm{Co}(1)$ & $126.6(2)$ \\
\hline $\mathrm{O}(8)-\mathrm{C}(78)$ & $1.217(6)$ & $\mathrm{C}(35)-\mathrm{O}(3)-\mathrm{Co}(2)$ & $122.8(2)$ \\
\hline $\mathrm{N}(1)-\mathrm{C}(20)$ & $1.479(4)$ & $\mathrm{C}(68)-\mathrm{O}(4)-\mathrm{Co}(2)$ & $127.6(2)$ \\
\hline $\mathrm{N}(1)-\mathrm{C}(16)$ & $1.482(4)$ & $\mathrm{C}(69)-\mathrm{O}(5)-\mathrm{Co}(1)$ & $141.5(3)$ \\
\hline $\mathrm{N}(1)-\mathrm{C}(15)$ & $1.491(4)$ & $\mathrm{C}(72)-\mathrm{O}(6)-\mathrm{Co}(2)$ & $143.9(4)$ \\
\hline $\mathrm{N}(2)-\mathrm{C}(18)$ & $1.472(5)$ & $\mathrm{C}(20)-\mathrm{N}(1)-\mathrm{C}(16)$ & $112.9(3)$ \\
\hline $\mathrm{N}(2)-\mathrm{C}(19)$ & $1.487(5)$ & $\mathrm{C}(20)-\mathrm{N}(1)-\mathrm{C}(15)$ & $110.1(3)$ \\
\hline $\mathrm{N}(2)-\mathrm{C}(17)$ & $1.492(4)$ & $\mathrm{C}(16)-\mathrm{N}(1)-\mathrm{C}(15)$ & $109.5(3)$ \\
\hline $\mathrm{N}(3)-\mathrm{C}(50)$ & $1.475(4)$ & $\mathrm{C}(20)-\mathrm{N}(1)-\mathrm{Co}(1)$ & $108.82(19)$ \\
\hline $\mathrm{N}(3)-\mathrm{C}(49)$ & $1.480(4)$ & $\mathrm{C}(16)-\mathrm{N}(1)-\mathrm{Co}(1)$ & $106.40(19)$ \\
\hline $\mathrm{N}(3)-\mathrm{C}(54)$ & $1.490(4)$ & $\mathrm{C}(15)-\mathrm{N}(1)-\mathrm{Co}(1)$ & $109.0(2)$ \\
\hline $\mathrm{N}(4)-\mathrm{C}(52)$ & $1.473(5)$ & $\mathrm{C}(18)-\mathrm{N}(2)-\mathrm{Co}(1)$ & $114.6(2)$ \\
\hline $\mathrm{N}(4)-\mathrm{C}(53)$ & $1.484(5)$ & $\mathrm{C}(19)-\mathrm{N}(2)-\mathrm{Co}(1)$ & $106.3(2)$ \\
\hline $\mathrm{N}(4)-\mathrm{C}(51)$ & $1.487(5)$ & $\mathrm{C}(17)-\mathrm{N}(2)-\mathrm{Co}(1)$ & $108.1(2)$ \\
\hline $\mathrm{O}(1)-\mathrm{Co}(1)-\mathrm{O}(2)$ & $120.64(11)$ & $\mathrm{C}(50)-\mathrm{N}(3)-\mathrm{Co}(2)$ & $107.7(2)$ \\
\hline $\mathrm{O}(1)-\mathrm{Co}(1)-\mathrm{N}(1)$ & $92.33(11)$ & $\mathrm{C}(49)-\mathrm{N}(3)-\mathrm{Co}(2)$ & $109.4(2)$ \\
\hline $\mathrm{O}(2)-\mathrm{Co}(1)-\mathrm{N}(1)$ & $93.12(10)$ & $\mathrm{C}(54)-\mathrm{N}(3)-\mathrm{Co}(2)$ & $111.96(19)$ \\
\hline $\mathrm{O}(1)-\mathrm{Co}(1)-\mathrm{N}(2)$ & $125.90(12)$ & $\mathrm{C}(52)-\mathrm{N}(4)-\mathrm{Co}(2)$ & $113.4(2)$ \\
\hline \multirow[t]{2}{*}{$\mathrm{O}(2)-\mathrm{Co}(1)-\mathrm{N}(2)$} & $113.43(11)$ & $\mathrm{C}(53)-\mathrm{N}(4)-\mathrm{Co}(2)$ & $107.8(2)$ \\
\hline & & $\mathrm{C}(51)-\mathrm{N}(4)-\mathrm{Co}(2)$ & $107.3(2)$ \\
\hline
\end{tabular}

dioxide. Although this complex contains $\mathrm{Co}^{\mathrm{II}}$ rather than $\mathrm{Co}^{\text {III }}$, this compound may potentially act as model for the higher oxidation state analog. Furthermore, there are relatively few $\mathrm{Co}^{\mathrm{II}}$ phenolate complexes that also contain ethereal ligands in the coordination 
Table 3 Selected bond lengths $[\AA]$ and angles $\left[{ }^{\circ}\right]$ for the methanol adduct of 1

\begin{tabular}{llll}
\hline $\mathrm{Co}(1)-\mathrm{O}(1)$ & $1.930(2)$ & $\mathrm{O}(4)-\mathrm{Co}(2)-\mathrm{O}(6)$ & $90.97(9)$ \\
$\mathrm{Co}(1)-\mathrm{O}(2)$ & $1.972(2)$ & $\mathrm{O}(3)-\mathrm{Co}(2)-\mathrm{O}(6)$ & $90.98(9)$ \\
$\mathrm{Co}(1)-\mathrm{N}(1)$ & $2.142(3)$ & $\mathrm{N}(4)-\mathrm{Co}(2)-\mathrm{O}(6)$ & $91.88(9)$ \\
$\mathrm{Co}(1)-\mathrm{N}(2)$ & $2.153(3)$ & $\mathrm{O}(4)-\mathrm{Co}(2)-\mathrm{N}(3)$ & $92.73(9)$ \\
$\mathrm{Co}(1)-\mathrm{O}(5)$ & $2.154(2)$ & $\mathrm{O}(3)-\mathrm{Co}(2)-\mathrm{N}(3)$ & $90.57(9)$ \\
$\mathrm{Co}(2)-\mathrm{O}(4)$ & $1.935(2)$ & $\mathrm{N}(4)-\mathrm{Co}(2)-\mathrm{N}(3)$ & $82.39(9)$ \\
$\mathrm{Co}(2)-\mathrm{O}(3)$ & $1.982(2)$ & $\mathrm{O}(6)-\mathrm{Co}(2)-\mathrm{N}(3)$ & $174.06(9)$ \\
$\mathrm{Co}(2)-\mathrm{N}(4)$ & $2.142(2)$ & $\mathrm{C}(1)-\mathrm{O}(1)-\mathrm{Co}(1)$ & $128.01(18)$ \\
$\mathrm{Co}(2)-\mathrm{O}(6)$ & $2.147(2)$ & $\mathrm{C}(34)-\mathrm{O}(2)-\mathrm{Co}(1)$ & $124.89(19)$ \\
$\mathrm{Co}(2)-\mathrm{N}(3)$ & $2.176(2)$ & $\mathrm{C}(35)-\mathrm{O}(3)-\mathrm{Co}(2)$ & $121.12(18)$ \\
$\mathrm{O}(1)-\mathrm{C}(1)$ & $1.333(3)$ & $\mathrm{C}(68)-\mathrm{O}(4)-\mathrm{Co}(2)$ & $123.91(18)$ \\
$\mathrm{O}(2)-\mathrm{C}(34)$ & $1.351(4)$ & $\mathrm{C}(69)-\mathrm{O}(5)-\mathrm{Co}(1)$ & $121.1(2)$ \\
$\mathrm{O}(1)-\mathrm{Co}(1)-\mathrm{O}(2)$ & $117.11(9)$ & $\mathrm{C}(70)-\mathrm{O}(6)-\mathrm{Co}(2)$ & $125.1(2)$ \\
$\mathrm{O}(1)-\mathrm{Co}(1)-\mathrm{N}(1)$ & $92.89(9)$ & $\mathrm{C}(16)-\mathrm{N}(1)-\mathrm{Co}(1)$ & $107.97(19)$ \\
$\mathrm{O}(2)-\mathrm{Co}(1)-\mathrm{N}(1)$ & $90.77(9)$ & $\mathrm{C}(15)-\mathrm{N}(1)-\mathrm{Co}(1)$ & $109.68(18)$ \\
$\mathrm{O}(1)-\mathrm{Co}(1)-\mathrm{N}(2)$ & $112.44(9)$ & $\mathrm{C}(20)-\mathrm{N}(1)-\mathrm{Co}(1)$ & $108.49(18)$ \\
$\mathrm{O}(2)-\mathrm{Co}(1)-\mathrm{N}(2)$ & $130.18(9)$ & $\mathrm{C}(17)-\mathrm{N}(2)-\mathrm{Co}(1)$ & $108.12(19)$ \\
$\mathrm{N}(1)-\mathrm{Co}(1)-\mathrm{N}(2)$ & $81.83(10)$ & $\mathrm{C}(19)-\mathrm{N}(2)-\mathrm{Co}(1)$ & $115.36(19)$ \\
$\mathrm{O}(1)-\mathrm{Co}(1)-\mathrm{O}(5)$ & $95.18(9)$ & $\mathrm{C}(18)-\mathrm{N}(2)-\mathrm{Co}(1)$ & $106.41(18)$ \\
$\mathrm{O}(2)-\mathrm{Co}(1)-\mathrm{O}(5)$ & $90.91(9)$ & $\mathrm{C}(54)-\mathrm{N}(3)-\mathrm{Co}(2)$ & $109.21(17)$ \\
$\mathrm{N}(1)-\mathrm{Co}(1)-\mathrm{O}(5)$ & $169.93(9)$ & $\mathrm{C}(50)-\mathrm{N}(3)-\mathrm{Co}(2)$ & $107.44(17)$ \\
$\mathrm{N}(2)-\mathrm{Co}(1)-\mathrm{O}(5)$ & $89.50(9)$ & $\mathrm{C}(49)-\mathrm{N}(3)-\mathrm{Co}(2)$ & $110.46(18)$ \\
$\mathrm{O}(4)-\mathrm{Co}(2)-\mathrm{O}(3)$ & $126.29(9)$ & $\mathrm{C}(51)-\mathrm{N}(4)-\mathrm{Co}(2)$ & $106.19(17)$ \\
$\mathrm{O}(4)-\mathrm{Co}(2)-\mathrm{N}(4)$ & $113.03(9)$ & $\mathrm{C}(52)-\mathrm{N}(4)-\mathrm{Co}(2)$ & $113.40(19)$ \\
$\mathrm{O}(3)-\mathrm{Co}(2)-\mathrm{N}(4)$ & $120.53(9)$ & $\mathrm{C}(53)-\mathrm{N}(4)-\mathrm{Co}(2)$ & $109.86(18)$ \\
\hline & & &
\end{tabular}

Table 4 Selected bond lengths $[\AA]$ and angles $\left[{ }^{\circ}\right]$ for the propylene oxide adduct of 1

\begin{tabular}{|c|c|c|c|}
\hline $\mathrm{Co}(1)-\mathrm{O}(2)$ & $1.922(3)$ & $\mathrm{C}(34)-\mathrm{O}(2)-\mathrm{Co}(1)$ & $127.8(2)$ \\
\hline $\mathrm{Co}(1)-\mathrm{O}(1)$ & $1.930(3)$ & $\mathrm{C}(35)-\mathrm{O}(3)-\mathrm{Co}(2)$ & $123.2(2)$ \\
\hline $\mathrm{Co}(1)-\mathrm{N}(1)$ & $2.123(3)$ & $\mathrm{C}(71)-\mathrm{O}(4)-\mathrm{Co}(2)$ & $126.7(2)$ \\
\hline $\mathrm{Co}(1)-\mathrm{N}(2)$ & $2.132(4)$ & $\mathrm{C}(74)-\mathrm{O}(5)-\mathrm{C}(73)$ & $59.1(5)$ \\
\hline $\mathrm{Co}(1)-\mathrm{O}(5)$ & $2.220(3)$ & $\mathrm{C}(74)-\mathrm{O}(5)-\mathrm{Co}(1)$ & $123.7(3)$ \\
\hline $\mathrm{Co}(2)-\mathrm{O}(4)$ & $1.925(3)$ & $\mathrm{C}(73)-\mathrm{O}(5)-\mathrm{Co}(1)$ & $123.3(4)$ \\
\hline $\mathrm{Co}(2)-\mathrm{O}(3)$ & $1.935(3)$ & $\mathrm{C}(77)-\mathrm{O}(6)-\mathrm{C}(78)$ & $59.1(4)$ \\
\hline $\mathrm{Co}(2)-\mathrm{N}(4)$ & $2.129(4)$ & $\mathrm{C}(77)-\mathrm{O}(6)-\mathrm{Co}(2)$ & $130.1(3)$ \\
\hline $\mathrm{Co}(2)-\mathrm{N}(3)$ & $2.143(3)$ & $\mathrm{C}(78)-\mathrm{O}(6)-\mathrm{Co}(2)$ & $123.0(3)$ \\
\hline $\mathrm{Co}(2)-\mathrm{O}(6)$ & $2.219(3)$ & $\mathrm{C}(80)-\mathrm{O}(7)-\mathrm{C}(81)$ & $57.5(10)$ \\
\hline $\mathrm{O}(1)-\mathrm{C}(1)$ & $1.314(5)$ & $\mathrm{C}(15)-\mathrm{N}(1)-\mathrm{C}(16)$ & $112.5(3)$ \\
\hline $\mathrm{O}(2)-\mathrm{C}(34)$ & $1.332(5)$ & $\mathrm{C}(15)-\mathrm{N}(1)-\mathrm{C}(20)$ & $110.1(3)$ \\
\hline $\mathrm{O}(3)-\mathrm{C}(35)$ & $1.341(4)$ & $\mathrm{C}(16)-\mathrm{N}(1)-\mathrm{C}(20)$ & $110.4(3)$ \\
\hline $\mathrm{O}(2)-\mathrm{Co}(1)-\mathrm{O}(1)$ & $119.55(13)$ & $\mathrm{C}(15)-\mathrm{N}(1)-\mathrm{Co}(1)$ & $108.2(2)$ \\
\hline $\mathrm{O}(2)-\mathrm{Co}(1)-\mathrm{N}(1)$ & $92.93(12)$ & $\mathrm{C}(16)-\mathrm{N}(1)-\mathrm{Co}(1)$ & $106.3(2)$ \\
\hline $\mathrm{O}(1)-\mathrm{Co}(1)-\mathrm{N}(1)$ & $94.14(12)$ & $\mathrm{C}(20)-\mathrm{N}(1)-\mathrm{Co}(1)$ & $109.2(2)$ \\
\hline $\mathrm{O}(2)-\mathrm{Co}(1)-\mathrm{N}(2)$ & $126.05(14)$ & $\mathrm{C}(19)-\mathrm{N}(2)-\mathrm{C}(17)$ & $110.3(4)$ \\
\hline $\mathrm{O}(1)-\mathrm{Co}(1)-\mathrm{N}(2)$ & $114.40(14)$ & $\mathrm{C}(19)-\mathrm{N}(2)-\mathrm{C}(18)$ & $108.2(4)$ \\
\hline $\mathrm{N}(1)-\mathrm{Co}(1)-\mathrm{N}(2)$ & $83.10(13)$ & $\mathrm{C}(17)-\mathrm{N}(2)-\mathrm{C}(18)$ & $109.8(4)$ \\
\hline $\mathrm{O}(2)-\mathrm{Co}(1)-\mathrm{O}(5)$ & $93.72(12)$ & $\mathrm{C}(19)-\mathrm{N}(2)-\mathrm{Co}(1)$ & $113.1(3)$ \\
\hline $\mathrm{O}(1)-\mathrm{Co}(1)-\mathrm{O}(5)$ & $88.38(13)$ & $\mathrm{C}(17)-\mathrm{N}(2)-\mathrm{Co}(1)$ & $108.5(3)$ \\
\hline $\mathrm{N}(1)-\mathrm{Co}(1)-\mathrm{O}(5)$ & $170.58(13)$ & $\mathrm{C}(18)-\mathrm{N}(2)-\mathrm{Co}(1)$ & $106.9(3)$ \\
\hline $\mathrm{N}(2)-\mathrm{Co}(1)-\mathrm{O}(5)$ & $87.58(14)$ & $\mathrm{C}(50)-\mathrm{N}(3)-\mathrm{C}(54)$ & $110.2(3)$ \\
\hline $\mathrm{O}(4)-\mathrm{Co}(2)-\mathrm{O}(3)$ & $120.93(12)$ & $\mathrm{C}(50)-\mathrm{N}(3)-\mathrm{C}(49)$ & $111.0(3)$ \\
\hline $\mathrm{O}(4)-\mathrm{Co}(2)-\mathrm{N}(4)$ & $115.94(13)$ & $\mathrm{C}(54)-\mathrm{N}(3)-\mathrm{C}(49)$ & $108.1(3)$ \\
\hline $\mathrm{O}(3)-\mathrm{Co}(2)-\mathrm{N}(4)$ & $123.13(13)$ & $\mathrm{C}(50)-\mathrm{N}(3)-\mathrm{Co}(2)$ & $107.3(2)$ \\
\hline $\mathrm{O}(4)-\mathrm{Co}(2)-\mathrm{N}(3)$ & $93.18(11)$ & $\mathrm{C}(54)-\mathrm{N}(3)-\mathrm{Co}(2)$ & $111.5(2)$ \\
\hline $\mathrm{O}(3)-\mathrm{Co}(2)-\mathrm{N}(3)$ & $94.22(11)$ & $\mathrm{C}(49)-\mathrm{N}(3)-\mathrm{Co}(2)$ & $108.8(2)$ \\
\hline $\mathrm{N}(4)-\mathrm{Co}(2)-\mathrm{N}(3)$ & $82.91(12)$ & $\mathrm{C}(52)-\mathrm{N}(4)-\mathrm{C}(51)$ & $108.8(3)$ \\
\hline $\mathrm{O}(4)-\mathrm{Co}(2)-\mathrm{O}(6)$ & $90.10(12)$ & $\mathrm{C}(52)-\mathrm{N}(4)-\mathrm{C}(53)$ & 108.3(3) \\
\hline $\mathrm{O}(3)-\mathrm{Co}(2)-\mathrm{O}(6)$ & $92.88(11)$ & $\mathrm{C}(51)-\mathrm{N}(4)-\mathrm{C}(53)$ & $110.8(3)$ \\
\hline $\mathrm{N}(4)-\mathrm{Co}(2)-\mathrm{O}(6)$ & $86.42(12)$ & $\mathrm{C}(52)-\mathrm{N}(4)-\mathrm{Co}(2)$ & $113.8(3)$ \\
\hline $\mathrm{N}(3)-\mathrm{Co}(2)-\mathrm{O}(6)$ & $169.23(12)$ & $\mathrm{C}(51)-\mathrm{N}(4)-\mathrm{Co}(2)$ & $107.3(2)$ \\
\hline $\mathrm{C}(1)-\mathrm{O}(1)-\mathrm{Co}(1)$ & $125.7(2)$ & $\mathrm{C}(53)-\mathrm{N}(4)-\mathrm{Co}(2)$ & $107.8(3)$ \\
\hline
\end{tabular}

sphere. A tetrameric $\mathrm{Co}^{\text {II }}$ catecholate complex containing THF ligands within the Co coordination sphere exhibits $\mathrm{Co}-\mathrm{O}_{\text {ether }}$ bond distances of between 2.089(12) $\AA$ and 2.225(12) $\AA^{95}$ The Co$\mathrm{O}_{\text {ether }}$ bond distances in $\mathbf{1}\left(\mathrm{C}_{3} \mathrm{H}_{6} \mathrm{O}\right)$ of $2.220(3) \AA$ and 2.219(3) $\AA$
Table 5 Selected bond lengths $[\AA ̊]$ and angles $\left[{ }^{\circ}\right]$ for $\mathbf{2}$

\begin{tabular}{llll}
\hline $\mathrm{Co}(1)-\mathrm{O}(1)$ & $1.8782(14)$ & $\mathrm{C}(14)-\mathrm{N}(1)-\mathrm{C}(7)$ & $110.62(17)$ \\
$\mathrm{Co}(1)-\mathrm{O}(2)$ & $1.8942(15)$ & $\mathrm{C}(8)-\mathrm{N}(1)-\mathrm{Co}(1)$ & $105.63(14)$ \\
$\mathrm{Co}(1)-\mathrm{N}(1)$ & $2.0616(18)$ & $\mathrm{C}(14)-\mathrm{N}(1)-\mathrm{Co}(1)$ & $108.80(13)$ \\
$\mathrm{Co}(1)-\mathrm{N}(2)$ & $2.0929(18)$ & $\mathrm{C}(7)-\mathrm{N}(1)-\mathrm{Co}(1)$ & $108.04(12)$ \\
$\mathrm{O}(1)-\mathrm{Co}(1)-\mathrm{O}(2)$ & $130.88(7)$ & $\mathrm{C}(9)-\mathrm{N}(2)-\mathrm{C}(12)$ & $110.42(19)$ \\
$\mathrm{O}(1)-\mathrm{Co}(1)-\mathrm{N}(1)$ & $98.85(7)$ & $\mathrm{C}(9)-\mathrm{N}(2)-\mathrm{C}(10)$ & $110.71(17)$ \\
$\mathrm{O}(2)-\mathrm{Co}(1)-\mathrm{N}(1)$ & $97.85(7)$ & $\mathrm{C}(12)-\mathrm{N}(2)-\mathrm{C}(10)$ & $111.93(19)$ \\
$\mathrm{O}(1)-\mathrm{Co}(1)-\mathrm{N}(2)$ & $115.15(7)$ & $\mathrm{C}(9)-\mathrm{N}(2)-\mathrm{Co}(1)$ & $104.49(14)$ \\
$\mathrm{O}(2)-\mathrm{Co}(1)-\mathrm{N}(2)$ & $111.59(7)$ & $\mathrm{C}(12)-\mathrm{N}(2)-\mathrm{Co}(1)$ & $109.40(14)$ \\
$\mathrm{N}(1)-\mathrm{Co}(1)-\mathrm{N}(2)$ & $86.93(8)$ & $\mathrm{C}(10)-\mathrm{N}(2)-\mathrm{Co}(1)$ & $109.63(13)$ \\
$\mathrm{C}(8)-\mathrm{N}(1)-\mathrm{C}(14)$ & $110.60(17)$ & $\mathrm{C}(1)-\mathrm{O}(1)-\mathrm{Co}(1)$ & $124.01(13)$ \\
$\mathrm{C}(8)-\mathrm{N}(1)-\mathrm{C}(7)$ & $112.93(17)$ & $\mathrm{C}(15)-\mathrm{O}(2)-\mathrm{Co}(1)$ & $116.89(13)$ \\
\hline
\end{tabular}

are comparable to the longer bond distances reported therein. Structurally characterized adducts of propylene oxide and other epoxides with a range of other metals have been reported. ${ }^{96-100}$ In this context, the only M-phenolate complexes containing epoxides in the coordination sphere are $\mathrm{Cd}^{\mathrm{II}}$ and $\mathrm{Zn}^{\mathrm{II}}$ species. ${ }^{98}$ In these complexes, $\mathrm{M}-\mathrm{O}_{\text {ether }}$ bond distances are between 2.301(5) $\AA$ and 2.357(2) $\AA$ for $\mathrm{Cd}$ complexes and an average of 2.108(3) $\AA$ for the $\mathrm{Zn}$ species. Therefore, the $\mathrm{Co}-\mathrm{O}_{\text {ether }}$ bond distances in $\mathbf{1}\left(\mathrm{C}_{3} \mathrm{H}_{6} \mathrm{O}\right)$ show good agreement with literature precedents.

Although crystals suitable for X-ray analysis of the solvent-free complex $\mathrm{Co}\left[\mathrm{O}_{2} \mathrm{NN}^{\prime}\right]^{\mathrm{BuBuNM}}{ }^{\mathrm{Bu}}$ (1) could not be obtained, suitable crystals of $\mathrm{Co}\left[\mathrm{O}_{2} \mathrm{NN}^{\prime}\right]^{\mathrm{AmAmNE12}}$ (2) were grown from a toluene solution and contain four-coordinate $\mathrm{Co}^{\mathrm{II}}$ ions in a trigonal monopyramidal environment. The structure of $\mathbf{2}$ is shown in Fig. 5 with bond lengths and angles given in Table 5. Only a small number of complexes containing $\mathrm{Co}^{\text {II }}$ in this environment have been reported previously, ${ }^{101-103}$ and these generally contain trianionic ligands resulting in a net negatively charged complex. $\mathrm{Co}^{\mathrm{I}}$ in such a coordination geometry is also known. ${ }^{104}$ As far as we are aware, $\mathbf{2}$ is the first neutral coordination compound of $\mathrm{Co}^{\mathrm{II}}$ in a trigonal monopyramidal environment (where no counter cations or anions are required to balance the charge). It is noteworthy that the $\mathrm{Co}-\mathrm{O}_{\text {phenolate }}$ and $\mathrm{Co}-\mathrm{N}_{\text {amine }}$ bond distances in $\mathbf{2}$ are shorter than in the five coordinate complexes of $\mathbf{1}$ described above. Therefore, although $\left[\mathrm{O}_{2} \mathrm{NN}^{\prime}\right]^{\mathrm{AmAmNEt} 2}$ is more sterically demanding than $\left[\mathrm{O}_{2} \mathrm{NN}^{\prime}\right]^{\mathrm{BuBuNM} 2}$, the presence of additional small, Lewis bases in the coordination sphere of the Co has a significant effect on the electronics at the metal center and leads to a lengthening of the

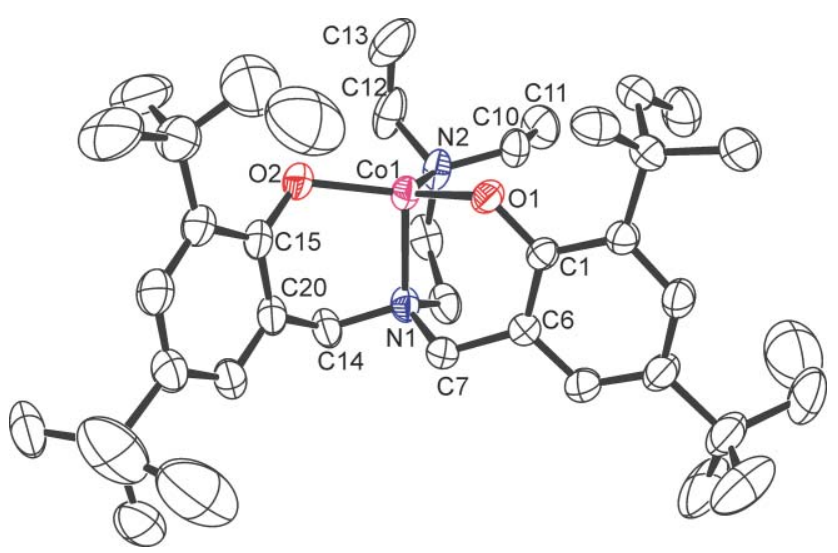

Fig. 5 ORTEP diagram of the molecular structure of $\mathbf{2}$ with $50 \%$ thermal ellipsoid probability. 
$\mathrm{Co}-\mathrm{O}$ and $\mathrm{Co}-\mathrm{N}$ bonds in solvento complexes of $\mathbf{1}$ compared to compound 2.

In addition to the cobalt complexes discussed above, a number of other trigonal monopyramidal coordination compounds have been reported during the past twenty years. ${ }^{105-115}$ These complexes are generally described as being derived from a trigonal bipyramidal geometry but contain a vacant coordination site. They can also be described as containing significantly distorted tetrahedral environments, as they are closer to this common four-coordinate environment than square planar. In general, distortions from a perfect trigonal monopyramidal environment are reported as the distance at which the metal atom sits above or below the meridional plane containing three donor atoms. In 2, Co(1) sits below the plane of $\mathrm{O}(1), \mathrm{O}(2)$ and $\mathrm{N}(2)$ towards $\mathrm{N}(1)$ by a distance of $0.172 \AA$. However, as far as we are aware no angular structural parameter has been developed to assess how ideal the trigonal monopyramidal environment is, unlike the known parameters for trigonal bipyramidal species: $\tau$, for coordination complexes ${ }^{83}$ and the method developed by Holmes for pentacoordinate main group compounds. ${ }^{116}$ We propose that Addison and Reedijk's $\tau$ parameter can be extended to describe an ideal trigonal monopyramidal geometry but as the largest angles in such an environment should be close to $120^{\circ}$ and the smallest close to $90^{\circ}$, the geometric parameter becomes $\tau^{\prime}=(\{\beta+90\}-\alpha) / 60$, where $\beta=$ the largest angle obtained between a meridional donor, the metal and the apical donor, and $\alpha=$ the largest donor-metal-donor angle in the meridional plane. Thereby, $\tau^{\prime}$ assesses trigonality in the same fashion as $\tau$, and the calculation is the same as if a dummy atom has been placed in the vacant coordination site (apical position) above the metal atom to form a trigonal bipyramidal environment from the trigonal monopyramidal complex. Therefore, for a perfect trigonal monopyramidal environment $\tau^{\prime}=1.0$ and for a tetrahedral environment $\tau^{\prime}=1.5$. For $\mathbf{2}, \tau^{\prime}=0.97$, and for other trigonal monopyramidal $\mathrm{Co}^{\mathrm{II}}$ complexes, $\tau^{\prime}=0.89,{ }^{103} 0.90,{ }^{101}$ and between 0.87 and $0.93 .{ }^{102}$

\section{Syntheses and structures of bimetallic complexes}

Reaction of cobaltous acetate with $\mathrm{H}_{2}\left[\mathrm{O}_{2} \mathrm{NN}^{\prime}\right]^{\mathrm{AmAmPy}}$ under basic conditions affords $\left\{\mathrm{Co}\left[\mathrm{O}_{2} \mathrm{NN}^{\prime}\right]^{\mathrm{AmAmPy}}\right\}_{2}$ as a crystalline material. Although the refinement of accurate metric parameters was not possible due to severe disorder of one $t$-amyl group, the structure and connectivity of $\mathbf{3}$ were confirmed by X-ray crystallography. It reveals that both cobalt centers are in distorted trigonal bipyramidal environments and one-phenolate donor from each ligand forms a bridge. A ball and stick representation of this structure is shown in Figure S1 in Electronic Supplementary Information. $\dagger$ This structure is very similar to previously prepared aminebis(phenolate) complexes of $\mathrm{Co}^{\mathrm{II}} .{ }^{45-48,86}$ However, the substituents on the aromatic rings in these compounds are generally less sterically demanding than those used in our study.

In the presence of methanol, dark red-purple crystals of $\mathbf{3}\left(\mathrm{CH}_{3} \mathrm{OH}\right)$ could be grown. The structure of $\mathbf{3}\left(\mathrm{CH}_{3} \mathrm{OH}\right)$ is shown in Fig. 6 with bond lengths and angles given in Table 6. This complex contains two $\mathrm{Co}^{\mathrm{II}}$ centers bridged by methanol. The geometry of each $\mathrm{Co}^{\mathrm{II}}$ center is best described as distorted octahedral and contains Co-phenolate bond distances of 1.9013(15) and 1.9157(15) ^, which are moderately shorter than the terminal Cophenolate bond distances in the related methanol-free bimetallic
Table 6 Selected bond lengths $[\AA]$ and angles $\left[{ }^{\circ}\right]$ for the methanol adduct of 3

\begin{tabular}{llll}
\hline $\mathrm{Co}(1)-\mathrm{O}(1)$ & $1.9013(15)$ & $\mathrm{O}(1)-\mathrm{Co}(1)-\mathrm{O}(3)$ & $89.86(7)$ \\
$\mathrm{Co}(1)-\mathrm{N}(2)$ & $1.9150(17)$ & $\mathrm{N}(2)-\mathrm{Co}(1)-\mathrm{O}(3)$ & $93.34(7)$ \\
$\mathrm{Co}(1)-\mathrm{O}(2)$ & $1.9157(15)$ & $\mathrm{O}(2)-\mathrm{Co}(1)-\mathrm{O}(3)$ & $171.71(6)$ \\
$\mathrm{Co}(1)-\mathrm{O}(3)$ & $1.9326(15)$ & $\mathrm{O}(3)-\mathrm{Co}(1)-\mathrm{O}(3)^{\prime}$ & $80.33(7)$ \\
$\mathrm{Co}(1)-\mathrm{N}(1)$ & $1.9505(17)$ & $\mathrm{N}(1)-\mathrm{Co}(1)-\mathrm{O}(3)$ & $93.97(7)$ \\
$\mathrm{Co}(1)-\mathrm{O}(3)$ & $1.9522(15)$ & $\mathrm{O}(1)-\mathrm{Co}(1)-\mathrm{Co}(1)$ & $88.21(4)$ \\
$\mathrm{Co}(1)-\mathrm{Co}(1)$ & $2.9688(10)$ & $\mathrm{N}(2)-\mathrm{Co}(1)-\mathrm{Co}(1)$ & $94.08(5)$ \\
$\mathrm{O}(1)-\mathrm{C}(1)$ & $1.334(2)$ & $\mathrm{O}(2)-\mathrm{Co}(1)-\mathrm{Co}(1)$ & $132.09(4)$ \\
$\mathrm{O}(2)-\mathrm{C}(40)$ & $1.337(2)$ & $\mathrm{O}(3)-\mathrm{Co}(1)-\mathrm{Co}(1)$ & $40.41(4)$ \\
$\mathrm{O}(3)-\mathrm{C}(41)$ & $1.436(3)$ & $\mathrm{N}(1)-\mathrm{Co}(1)-\mathrm{Co}(1)$ & $133.86(5)$ \\
$\mathrm{O}(3)-\mathrm{Co}(1)$ & $1.9522(14)$ & $\mathrm{O}(3)-\mathrm{Co}(1)-\mathrm{Co}(1)$ & $39.92(4)$ \\
$\mathrm{N}(1)-\mathrm{C}(18)$ & $1.496(2)$ & $\mathrm{C}(1)-\mathrm{O}(1)-\mathrm{Co}(1)$ & $126.55(12)$ \\
$\mathrm{N}(1)-\mathrm{C}(24)$ & $1.501(2)$ & $\mathrm{C}(40)-\mathrm{O}(2)-\mathrm{Co}(1)$ & $119.46(12)$ \\
$\mathrm{N}(1)-\mathrm{C}(17)$ & $1.502(3)$ & $\mathrm{C}(41)-\mathrm{O}(3)-\mathrm{Co}(1)$ & $112.14(14)$ \\
$\mathrm{N}(2)-\mathrm{C}(23)$ & $1.340(3)$ & $\mathrm{C}(41)-\mathrm{O}(3)-\mathrm{Co}(1)$ & $118.89(14)$ \\
$\mathrm{N}(2)-\mathrm{C}(19)$ & $1.346(3)$ & $\mathrm{Co}(1)-\mathrm{O}(3)-\mathrm{Co}(1)^{\prime}$ & $99.67(6)$ \\
$\mathrm{O}(1)-\mathrm{Co}(1)-\mathrm{N}(2)$ & $176.79(6)$ & $\mathrm{C}(18)-\mathrm{N}(1)-\mathrm{C}(24)$ & $108.99(15)$ \\
$\mathrm{O}(1)-\mathrm{Co}(1)-\mathrm{O}(2)$ & $87.44(7)$ & $\mathrm{C}(18)-\mathrm{N}(1)-\mathrm{C}(17)$ & $109.70(16)$ \\
$\mathrm{N}(2)-\mathrm{Co}(1)-\mathrm{O}(2)$ & $89.35(7)$ & $\mathrm{C}(24)-\mathrm{N}(1)-\mathrm{C}(17)$ & $110.16(15)$ \\
$\mathrm{O}(1)-\mathrm{Co}(1)-\mathrm{O}(3)$ & $87.39(6)$ & $\mathrm{C}(18)-\mathrm{N}(1)-\mathrm{Co}(1)$ & $106.76(12)$ \\
$\mathrm{N}(2)-\mathrm{Co}(1)-\mathrm{O}(3)$ & $92.89(7)$ & $\mathrm{C}(24)-\mathrm{N}(1)-\mathrm{Co}(1)$ & $112.34(12)$ \\
$\mathrm{O}(2)-\mathrm{Co}(1)-\mathrm{O}(3)$ & $91.72(6)$ & $\mathrm{C}(17)-\mathrm{N}(1)-\mathrm{Co}(1)$ & $108.83(11)$ \\
$\mathrm{O}(1)-\mathrm{Co}(1)-\mathrm{N}(1)$ & $94.40(6)$ & $\mathrm{C}(23)-\mathrm{N}(2)-\mathrm{C}(19)$ & $120.14(18)$ \\
$\mathrm{N}(2)-\mathrm{Co}(1)-\mathrm{N}(1)$ & $85.64(7)$ & $\mathrm{C}(23)-\mathrm{N}(2)-\mathrm{Co}(1)$ & $124.70(14)$ \\
$\mathrm{O}(2)-\mathrm{Co}(1)-\mathrm{N}(1)$ & $94.05(7)$ & $\mathrm{C}(19)-\mathrm{N}(2)-\mathrm{Co}(1)$ & $114.22(14)$ \\
$\mathrm{O}(3)-\mathrm{Co}(1)-\mathrm{N}(1)$ & $174.03(6)$ & &
\end{tabular}

$\mathrm{O}(3)-\mathrm{Co}(1)-\mathrm{N}(1) \quad 174.03(6)$

Symmetry transformation: $-x+2,-y+1,-z+2$

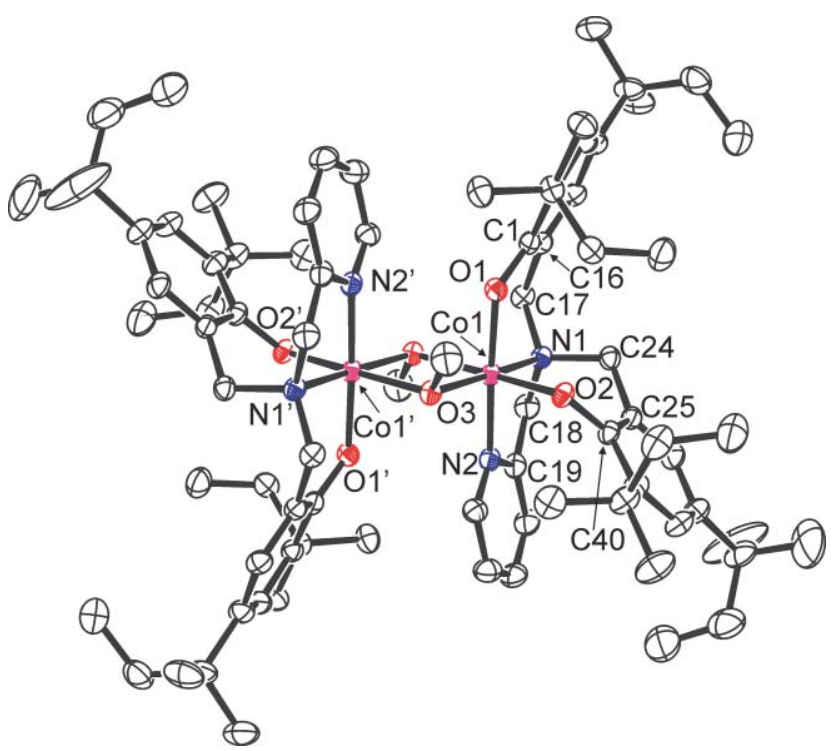

Fig. 6 ORTEP diagram of the molecular structure of the methanol adduct of 3 with $50 \%$ thermal ellipsoid probability.

cobalt complexes that possess bond distances between 1.9222(12) and $1.935(3) \AA \AA^{45-48,86}$ Interestingly, one of these known complexes is asymmetric, ${ }^{48}$ containing one octahedral Co center with a coordinated methanol molecule, however the phenolates remain in their bridging positions. In $3\left(\mathrm{CH}_{3} \mathrm{OH}\right)$, the bridging positions are taken up by the smaller methanol donors, this is presumably due to the steric demands of the ortho $t$-amyl groups on the phenolate donors as the previously described complexes contain small or no ortho substituents. The $\mathrm{Co}-\mathrm{O}$ bond distance for the bridging methanols in $\mathbf{3}\left(\mathrm{CH}_{3} \mathrm{OH}\right)$ is $1.9326(15) \AA$ and is shorter than the terminal Co-methanol interaction in the previously described 
cobalt amine-bis(phenolate) complex. ${ }^{48}$ It should also be noted that the $\mathrm{Co}-\mathrm{N}$ bond distances within $\mathbf{3}\left(\mathrm{CH}_{3} \mathrm{OH}\right)$ are significantly shorter $(1.9150(17) \AA$ and $1.9505(17) \AA)$ than those in previously reported $\mathrm{Co}^{\mathrm{II}}$ amine-bis(phenolate) complexes, 2.156(3)2.1982(14) $\AA$ for Co-apical N bonds and 2.066(4)-2.119(4) $\AA$ for Co-pyridyl bonds. ${ }^{4-48,86}$ The reason for the shorter bond distances within the Co coordination sphere of $\mathbf{3}\left(\mathrm{CH}_{3} \mathrm{OH}\right)$ compared with related complexes may be due to a difference in oxidation- or spin-state. In comparing $\mathbf{3}\left(\mathrm{CH}_{3} \mathrm{OH}\right)$ with the solvento complexes of $\mathbf{1}$ and complex $\mathbf{2}, \mathrm{Co}-\mathrm{O}_{\text {phenolate }}$ bond distances are intermediate of the two classes of monometallic complex but $\mathrm{Co}-\mathrm{N}_{\text {amine }}$ bond distances are significantly shorter in $\mathbf{3}\left(\mathrm{CH}_{3} \mathrm{OH}\right)$. The previously studied phenolate-bridged complexes, where magnetic data are reported, contain two high-spin $\mathrm{Co}^{\mathrm{II}}$ centers.

The shortening of bond lengths around the Co centres in $3\left(\mathrm{CH}_{3} \mathrm{OH}\right)$ may be due to low-spin $d^{7}$ electron configurations. Alternatively, the shorter bond distances in $\mathbf{3}\left(\mathrm{CH}_{3} \mathrm{OH}\right)$ compared to the reported phenolate-bridged $\mathrm{Co}^{\mathrm{II}}$ complexes may indicate the metal centers in $3\left(\mathrm{CH}_{3} \mathrm{OH}\right)$ are actually $\mathrm{Co}^{\mathrm{III}}$ ions and the bridging ligands are in fact methoxides. The structural data were re-examined in attempt to locate the HO-protons of the methanol ligands. Electron density could be located in the difference map on the methanol oxygen atom, suggesting the bridging ligand is indeed methanol rather than methoxide. However, this alone is insufficient to unequivocally determine whether the bridging ligands are methanol or methoxide. Spectroscopic and magnetic data (see below) may provide some insight into the nature of $3\left(\mathrm{CH}_{3} \mathrm{OH}\right)$.

\section{Syntheses and structures of trimetallic complexes}

In the presence of excess cobaltous acetate during the synthetic procedure and in the absence of base, trimetallic complexes 4-6 were isolated that contain two $\mathrm{Co}\left[\mathrm{O}_{2} \mathrm{NN}^{\prime}\right]^{R R^{\prime}}$ fragments bridged with a $\mathrm{Co}(\mathrm{OAc})_{2}\left(\mathrm{CH}_{3} \mathrm{OH}\right)_{4}$ unit (Scheme 2). The structures of 5 and 6 are shown in Fig. 7 and 8, respectively. Bond lengths and angles for 4, 5 and $\mathbf{6}$ are given in Tables 7, 8 and 9,

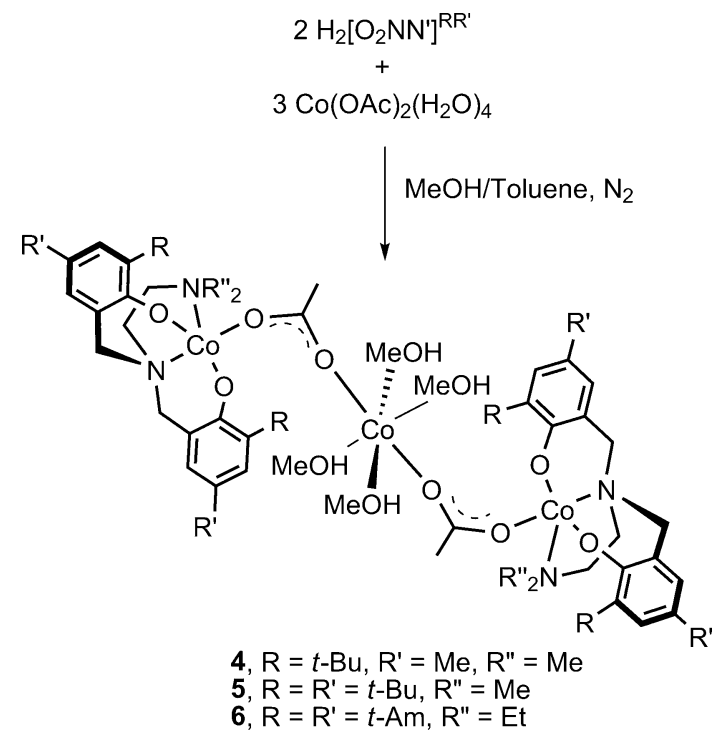

Scheme 2 Syntheses of trimetallic amine-bis(phenolate) complexes of $\mathrm{Co}^{\mathrm{II}}$.

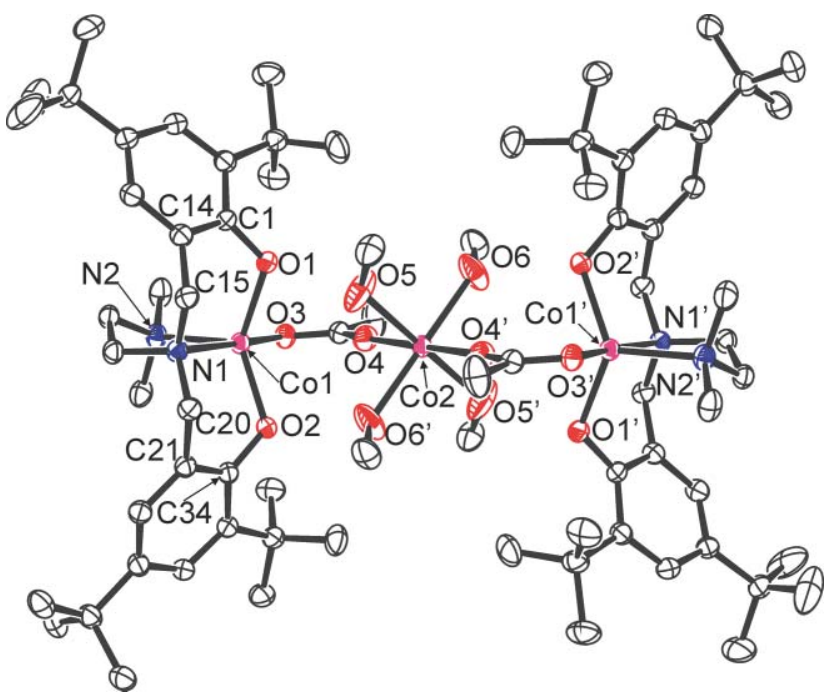

Fig. 7 ORTEP diagram of the molecular structure of 5 with $50 \%$ thermal ellipsoid probability.

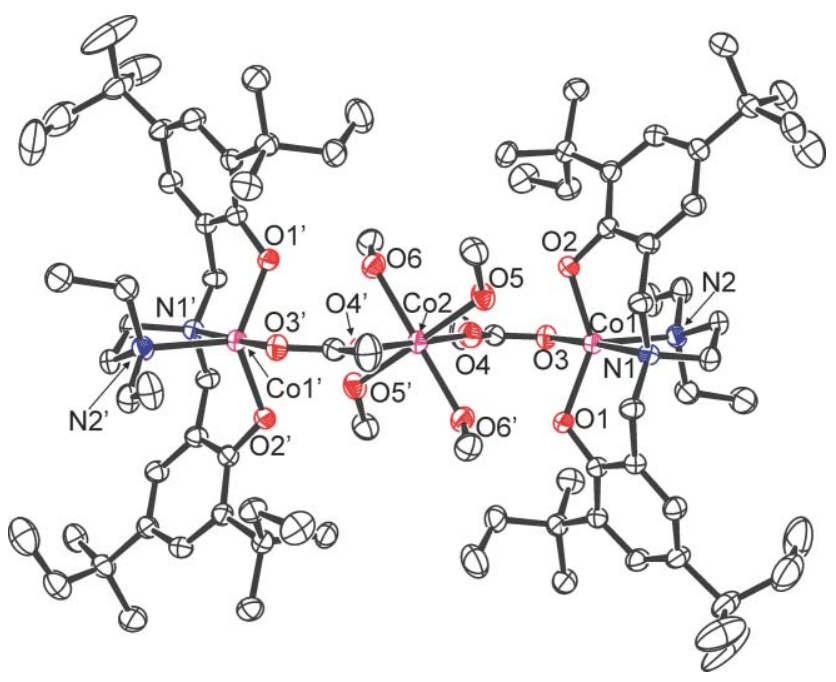

Fig. 8 ORTEP diagram of the molecular structure of 6 with $50 \%$ thermal ellipsoid probability.

respectively. The bridging cobalt unit contains a $\mathrm{Co}^{\text {II }}$ ion in a nearly perfect octahedral environment whereas the terminal cobalt amine-bis(phenolate) units possess distorted trigonal bipyramidal geometries, $t=0.62,0.65$ and 0.75 respectively for 4-6. The compounds are centrosymmetric and contain an inversion centre on $\mathrm{Co}(2)$. No differences are observed between the three structures in terms of $\mathrm{Co}-\mathrm{O}_{\text {phenolate }}(1.9899(14)-2.004(2) \AA)$ and $\mathrm{Co}-\mathrm{N}_{\text {amine }}$ (2.148(3)-2.242(2) $\AA$ ) bond distances.

In comparison with the structures of $\mathbf{1}$ (solvent), $\mathbf{2}$ and $3\left(\mathrm{CH}_{3} \mathrm{OH}\right)$, the $\mathrm{Co}-\mathrm{O}_{\text {phenolate }}$ bond distances are slightly longer than the monometallic and bimetallic species whereas the Co$\mathrm{N}_{\text {amine }}$ distances are comparable with $\mathbf{1}$ (solvent) and $\mathbf{2}$ but longer than $3\left(\mathrm{CH}_{3} \mathrm{OH}\right)$. As far as we are aware these complexes are the first $\mathrm{Co}^{\mathrm{II}}$ phenolate derivatives containing unsupported acetate bridges. Previous examples of $\mathrm{Co}^{\mathrm{II}}$ trimetallic species contain either multiple acetate (or trifluoroacetate) bridges between the metal centres or have phenolate bridges in addition to the acetate bridges. ${ }^{117-121}$ The bridging acetate O-Co bond distances in 4-6 
Table 7 Selected bond lengths $[\AA]$ and angles $\left[{ }^{\circ}\right]$ for $\mathbf{4}$

\begin{tabular}{llll}
\hline $\mathrm{Co}(1)-\mathrm{O}(1)$ & $1.9899(14)$ & $\mathrm{O}(4)-\mathrm{Co}(2)-\mathrm{O}(4)$ & 180.0 \\
$\mathrm{Co}(1)-\mathrm{O}(2)$ & $1.9982(14)$ & $\mathrm{O}(5)-\mathrm{Co}(2)-\mathrm{O}(6)$ & $90.70(7)$ \\
$\mathrm{Co}(1)-\mathrm{O}(3)$ & $2.0540(15)$ & $\mathrm{O}(4)-\mathrm{Co}(2)-\mathrm{O}(6)$ & $96.12(7)$ \\
$\mathrm{Co}(1)-\mathrm{N}(2)$ & $2.1532(17)$ & $\mathrm{O}(6)-\mathrm{Co}(2)-\mathrm{O}(6)$ & 180.0 \\
$\mathrm{Co}(1)-\mathrm{N}(1)$ & $2.2319(17)$ & $\mathrm{C}(1)-\mathrm{O}(1)-\mathrm{Co}(1)$ & $125.81(12)$ \\
$\mathrm{Co}(2)-\mathrm{O}(5)$ & $2.0647(15)$ & $\mathrm{C}(28)-\mathrm{O}(2)-\mathrm{Co}(1)$ & $121.08(12)$ \\
$\mathrm{Co}(2)-\mathrm{O}(4)$ & $2.0732(16)$ & $\mathrm{C}(29)-\mathrm{O}(3)-\mathrm{Co}(1)$ & $112.45(14)$ \\
$\mathrm{Co}(2)-\mathrm{O}(6)$ & $2.0938(15)$ & $\mathrm{C}(29)-\mathrm{O}(4)-\mathrm{Co}(2)$ & $169.73(17)$ \\
$\mathrm{O}(1)-\mathrm{C}(1)$ & $1.348(2)$ & $\mathrm{C}(31)-\mathrm{O}(5)-\mathrm{Co}(2)$ & $126.69(14)$ \\
$\mathrm{O}(2)-\mathrm{C}(28)$ & $1.350(2)$ & $\mathrm{C}(32)-\mathrm{O}(6)-\mathrm{Co}(2)$ & $123.08(16)$ \\
$\mathrm{O}(1)-\mathrm{Co}(1)-\mathrm{O}(2)$ & $136.11(6)$ & $\mathrm{C}(13)-\mathrm{N}(1)-\mathrm{C}(12)$ & $110.14(15)$ \\
$\mathrm{O}(1)-\mathrm{Co}(1)-\mathrm{O}(3)$ & $92.51(6)$ & $\mathrm{C}(13)-\mathrm{N}(1)-\mathrm{C}(17)$ & $111.19(16)$ \\
$\mathrm{O}(2)-\mathrm{Co}(1)-\mathrm{O}(3)$ & $95.00(6)$ & $\mathrm{C}(12)-\mathrm{N}(1)-\mathrm{C}(17)$ & $106.52(15)$ \\
$\mathrm{O}(1)-\mathrm{Co}(1)-\mathrm{N}(2)$ & $113.12(6)$ & $\mathrm{C}(13)-\mathrm{N}(1)-\mathrm{Co}(1)$ & $108.23(12)$ \\
$\mathrm{O}(2)-\mathrm{Co}(1)-\mathrm{N}(2)$ & $109.65(6)$ & $\mathrm{C}(12)-\mathrm{N}(1)-\mathrm{Co}(1)$ & $111.21(12)$ \\
$\mathrm{O}(3)-\mathrm{Co}(1)-\mathrm{N}(2)$ & $92.63(7)$ & $\mathrm{C}(17)-\mathrm{N}(1)-\mathrm{Co}(1)$ & $109.57(12)$ \\
$\mathrm{O}(1)-\mathrm{Co}(1)-\mathrm{N}(1)$ & $88.01(6)$ & $\mathrm{C}(15)-\mathrm{N}(2)-\mathrm{C}(16)$ & $108.32(19)$ \\
$\mathrm{O}(2)-\mathrm{Co}(1)-\mathrm{N}(1)$ & $89.31(6)$ & $\mathrm{C}(15)-\mathrm{N}(2)-\mathrm{C}(14)$ & $111.98(19)$ \\
$\mathrm{O}(3)-\mathrm{Co}(1)-\mathrm{N}(1)$ & $173.19(6)$ & $\mathrm{C}(16)-\mathrm{N}(2)-\mathrm{C}(14)$ & $108.40(18)$ \\
$\mathrm{N}(2)-\mathrm{Co}(1)-\mathrm{N}(1)$ & $80.93(6)$ & $\mathrm{C}(15)-\mathrm{N}(2)-\mathrm{Co}(1)$ & $109.05(14)$ \\
$\mathrm{O}(5)-\mathrm{Co}(2)-\mathrm{O}(5)$ & 180.0 & $\mathrm{C}(16)-\mathrm{N}(2)-\mathrm{Co}(1)$ & $110.70(14)$ \\
$\mathrm{O}(5)-\mathrm{Co}(2)-\mathrm{O}(4)$ & $86.86(7)$ & $\mathrm{C}(14)-\mathrm{N}(2)-\mathrm{Co}(1)$ & $108.39(13)$ \\
& & &
\end{tabular}

Symmetry transformation: $-x, y+\frac{1}{2},-z+\frac{1}{2}$

Table 8 Selected bond lengths $[\AA]$ and angles $\left[{ }^{\circ}\right]$ for 5

\begin{tabular}{llll}
\hline $\mathrm{Co}(1)-\mathrm{O}(2)$ & $1.995(2)$ & $\mathrm{O}(4)-\mathrm{Co}(2)-\mathrm{O}(4)$ & $179.996(1)$ \\
$\mathrm{Co}(1)-\mathrm{O}(1)$ & $2.004(2)$ & $\mathrm{O}(4)-\mathrm{Co}(2)-\mathrm{O}(5)$ & $86.85(11)$ \\
$\mathrm{Co}(1)-\mathrm{O}(3)$ & $2.049(2)$ & $\mathrm{O}(6)-\mathrm{Co}(2)-\mathrm{O}(5)$ & $90.58(18)$ \\
$\mathrm{Co}(1)-\mathrm{N}(2)$ & $2.148(3)$ & $\mathrm{O}(5)-\mathrm{Co}(2)-\mathrm{O}(5)$ & $180.00(14)$ \\
$\mathrm{Co}(1)-\mathrm{N}(1)$ & $2.241(3)$ & $\mathrm{C}(1)-\mathrm{O}(1)-\mathrm{Co}(1)$ & $121.08(18)$ \\
$\mathrm{Co}(2)-\mathrm{O}(6)$ & $2.061(3)$ & $\mathrm{C}(34)-\mathrm{O}(2)-\mathrm{Co}(1)$ & $123.48(18)$ \\
$\mathrm{Co}(2)-\mathrm{O}(4)$ & $2.070(2)$ & $\mathrm{C}(35)-\mathrm{O}(3)-\mathrm{Co}(1)$ & $112.42(19)$ \\
$\mathrm{Co}(2)-\mathrm{O}(5)$ & $2.076(3)$ & $\mathrm{C}(35)-\mathrm{O}(4)-\mathrm{Co}(2)$ & $171.5(2)$ \\
$\mathrm{O}(1)-\mathrm{C}(1)$ & $1.347(3)$ & $\mathrm{C}(37)-\mathrm{O}(5)-\mathrm{Co}(2)$ & $128.9(3)$ \\
$\mathrm{O}(2)-\mathrm{C}(34)$ & $1.346(3)$ & $\mathrm{C}(38)-\mathrm{O}(6)-\mathrm{Co}(2)$ & $126.7(3)$ \\
$\mathrm{O}(2)-\mathrm{Co}(1)-\mathrm{O}(1)$ & $133.91(9)$ & $\mathrm{C}(16)-\mathrm{N}(1)-\mathrm{C}(20)$ & $109.8(2)$ \\
$\mathrm{O}(2)-\mathrm{Co}(1)-\mathrm{O}(3)$ & $94.39(9)$ & $\mathrm{C}(16)-\mathrm{N}(1)-\mathrm{C}(15)$ & $111.1(2)$ \\
$\mathrm{O}(1)-\mathrm{Co}(1)-\mathrm{O}(3)$ & $94.51(9)$ & $\mathrm{C}(20)-\mathrm{N}(1)-\mathrm{C}(15)$ & $107.1(2)$ \\
$\mathrm{O}(2)-\mathrm{Co}(1)-\mathrm{N}(2)$ & $114.17(10)$ & $\mathrm{C}(16)-\mathrm{N}(1)-\mathrm{Co}(1)$ & $108.18(18)$ \\
$\mathrm{O}(1)-\mathrm{Co}(1)-\mathrm{N}(2)$ & $110.60(10)$ & $\mathrm{C}(20)-\mathrm{N}(1)-\mathrm{Co}(1)$ & $110.67(18)$ \\
$\mathrm{O}(3)-\mathrm{Co}(1)-\mathrm{N}(2)$ & $91.96(9)$ & $\mathrm{C}(15)-\mathrm{N}(1)-\mathrm{Co}(1)$ & $109.94(17)$ \\
$\mathrm{O}(2)-\mathrm{Co}(1)-\mathrm{N}(1)$ & $88.23(9)$ & $\mathrm{C}(18)-\mathrm{N}(2)-\mathrm{C}(19)$ & $108.2(3)$ \\
$\mathrm{O}(1)-\mathrm{Co}(1)-\mathrm{N}(1)$ & $88.53(9)$ & $\mathrm{C}(18)-\mathrm{N}(2)-\mathrm{C}(17)$ & $109.1(2)$ \\
$\mathrm{O}(3)-\mathrm{Co}(1)-\mathrm{N}(1)$ & $172.71(9)$ & $\mathrm{C}(19)-\mathrm{N}(2)-\mathrm{C}(17)$ & $110.4(2)$ \\
$\mathrm{N}(2)-\mathrm{Co}(1)-\mathrm{N}(1)$ & $80.77(9)$ & $\mathrm{C}(18)-\mathrm{N}(2)-\mathrm{Co}(1)$ & $111.0(2)$ \\
$\mathrm{O}(6)-\mathrm{Co}(2)-\mathrm{O}(6)$ & 180.0 & $\mathrm{C}(19)-\mathrm{N}(2)-\mathrm{Co}(1)$ & $109.70(19)$ \\
$\mathrm{O}(6)-\mathrm{Co}(2)-\mathrm{O}(4)$ & $95.30(11)$ & $\mathrm{C}(17)-\mathrm{N}(2)-\mathrm{Co}(1)$ & $108.39(18)$ \\
& & &
\end{tabular}

Symmetry transformation: $-x, y+\frac{1}{2},-z+\frac{1}{2}$

$(2.040(2)-2.0732(16) \AA)$ are comparable with those in previously reported $\mathrm{Co}^{\mathrm{II}}$ trimers. ${ }^{117,119,121}$ The $\mathrm{Co}-\mathrm{O}_{\text {methanol }}$ interactions for the central cobalt in 4-6 are comparable with known $\mathrm{Co}-\mathrm{O}$ bond distances for octahedral $\mathrm{Co}^{\mathrm{II}}$ species. ${ }^{122}$

\section{UV-visible spectroscopy}

The colour of the compounds provides some qualitative information. Compounds possessing five-coordinate Co ions $\left(\mathbf{1}\left(\mathrm{CH}_{3} \mathrm{OH}\right)\right.$, $\mathbf{1}\left(\mathrm{CH}_{3} \mathrm{COCH}_{3}\right), \mathbf{1}\left(\mathrm{C}_{3} \mathrm{H}_{6} \mathrm{O}\right), \mathbf{4}, \mathbf{5}$, and $\left.\mathbf{6}\right)$ are dark pink/purple. Four-coordinate $\mathbf{2}$ is dark green, the five-coordinate dimer $\mathbf{3}$ is yellow/orange, whereas six-coordinate $\mathbf{3}\left(\mathrm{CH}_{3} \mathrm{OH}\right)$ is dark red/purple. Electronic absorption spectra of complexes $\mathbf{1}$ to $\mathbf{6}$ show multiple intense bands in the UV and visible regions. The absorption maxima observed in the UV region (below $300 \mathrm{~nm}$ )
Table 9 Selected bond lengths $[\AA ̊]$ and angles $\left[{ }^{\circ}\right]$ for 6

\begin{tabular}{llll}
\hline $\mathrm{Co}(1)-\mathrm{O}(1)$ & $1.992(2)$ & $\mathrm{O}(5)-\mathrm{Co}(2)-\mathrm{O}(6)$ & $90.36(9)$ \\
$\mathrm{Co}(1)-\mathrm{O}(2)$ & $1.999(2)$ & $\mathrm{O}(6)-\mathrm{Co}(2)-\mathrm{O}(6)$ & 180.0 \\
$\mathrm{Co}(1)-\mathrm{O}(3)$ & $2.040(2)$ & $\mathrm{C}(1)-\mathrm{O}(1)-\mathrm{Co}(1)$ & $121.22(17)$ \\
$\mathrm{Co}(1)-\mathrm{N}(2)$ & $2.207(2)$ & $\mathrm{C}(40)-\mathrm{O}(2)-\mathrm{Co}(1)$ & $123.63(17)$ \\
$\mathrm{Co}(1)-\mathrm{N}(1)$ & $2.242(2)$ & $\mathrm{C}(41)-\mathrm{O}(3)-\mathrm{Co}(1)$ & $115.28(19)$ \\
$\mathrm{Co}(2)-\mathrm{O}(4)$ & $2.061(2)$ & $\mathrm{C}(41)-\mathrm{O}(4)-\mathrm{Co}(2)$ & $170.3(2)$ \\
$\mathrm{Co}(2)-\mathrm{O}(5)$ & $2.079(2)$ & $\mathrm{C}(43)-\mathrm{O}(5)-\mathrm{Co}(2)$ & $122.3(2)$ \\
$\mathrm{Co}(2)-\mathrm{O}(6)$ & $2.096(2)$ & $\mathrm{C}(44)-\mathrm{O}(6)-\mathrm{Co}(2)$ & $125.80(19)$ \\
$\mathrm{O}(1)-\mathrm{Co}(1)-\mathrm{O}(2)$ & $132.53(8)$ & $\mathrm{C}(18)-\mathrm{N}(1)-\mathrm{C}(24)$ & $110.1(2)$ \\
$\mathrm{O}(1)-\mathrm{Co}(1)-\mathrm{O}(3)$ & $93.80(8)$ & $\mathrm{C}(18)-\mathrm{N}(1)-\mathrm{C}(17)$ & $111.2(2)$ \\
$\mathrm{O}(2)-\mathrm{Co}(1)-\mathrm{O}(3)$ & $90.91(8)$ & $\mathrm{C}(24)-\mathrm{N}(1)-\mathrm{C}(17)$ & $106.5(2)$ \\
$\mathrm{O}(1)-\mathrm{Co}(1)-\mathrm{N}(2)$ & $109.27(9)$ & $\mathrm{C}(18)-\mathrm{N}(1)-\mathrm{Co}(1)$ & $108.19(17)$ \\
$\mathrm{O}(2)-\mathrm{Co}(1)-\mathrm{N}(2)$ & $116.77(9)$ & $\mathrm{C}(24)-\mathrm{N}(1)-\mathrm{Co}(1)$ & $110.87(17)$ \\
$\mathrm{O}(3)-\mathrm{Co}(1)-\mathrm{N}(2)$ & $97.91(9)$ & $\mathrm{C}(17)-\mathrm{N}(1)-\mathrm{Co}(1)$ & $109.93(17)$ \\
$\mathrm{O}(1)-\mathrm{Co}(1)-\mathrm{N}(1)$ & $88.71(8)$ & $\mathrm{C}(19)-\mathrm{N}(2)-\mathrm{C}(22)$ & $111.6(2)$ \\
$\mathrm{O}(2)-\mathrm{Co}(1)-\mathrm{N}(1)$ & $87.55(8)$ & $\mathrm{C}(19)-\mathrm{N}(2)-\mathrm{C}(20)$ & $105.8(2)$ \\
$\mathrm{O}(3)-\mathrm{Co}(1)-\mathrm{N}(1)$ & $177.48(9)$ & $\mathrm{C}(22)-\mathrm{N}(2)-\mathrm{C}(20)$ & $112.0(2)$ \\
$\mathrm{N}(2)-\mathrm{Co}(1)-\mathrm{N}(1)$ & $81.03(9)$ & $\mathrm{C}(19)-\mathrm{N}(2)-\mathrm{Co}(1)$ & $106.29(17)$ \\
$\mathrm{O}(4)-\mathrm{Co}(2)-\mathrm{O}(4)$ & $179.999(1)$ & $\mathrm{C}(22)-\mathrm{N}(2)-\mathrm{Co}(1)$ & $105.56(17)$ \\
$\mathrm{O}(4)-\mathrm{Co}(2)-\mathrm{O}(5)$ & $84.00(9)$ & $\mathrm{C}(20)-\mathrm{N}(2)-\mathrm{Co}(1)$ & $115.47(18)$ \\
$\mathrm{O}(4)-\mathrm{Co}(2)-\mathrm{O}(6)$ & $93.95(9)$ & &
\end{tabular}

Symmetry transformation: $-x, y+\frac{1}{2},-z+\frac{1}{2}$

are caused by $\pi \rightarrow \pi^{*}$ transitions involving the phenolate units absorptions in this region are also observed in the spectra of the unmetallated ligand precursors. ${ }^{33}$ Intense bands are also observed in the region between 300 and $450 \mathrm{~nm}$, which are assigned to charge transfer transitions from the $p_{\pi}$ orbital (HOMO) of the phenolate oxygen to the $d$ orbitals of $\mathrm{Co}^{\mathrm{II}}$. The broad charge transfer bands obscure the high-energy visible region where ligand field transitions would be expected, particularly in donor solvents such as methanol. For monomeric solvento complexes such as dark pink/purple $\mathbf{1}\left(\mathrm{CH}_{3} \mathrm{COCH}_{3}\right)$ in dichloromethane, the UV-vis spectrum (Fig. 9) shows weaker bands $(\varepsilon<200 \mathrm{~L}$ $\mathrm{mol}^{-1} \mathrm{~cm}^{-1}$ ) between 550 and $700 \mathrm{~nm}$, which can be assigned to $d-d$ transitions. ${ }^{47,48,86}$ The trigonal bipyramidal coordination at $\mathrm{Co}$ in the solvento complexes of $\mathbf{1}$ lowers the symmetry compared to a pure octahedral system, thereby easing the Laporte selection rule. It is difficult to unequivocally assign the observed bands to specific electronic transitions since high spin $\mathrm{Co}^{\text {II }}$ in a trigonal bipyramidal ligand field shows six spin-allowed electronic transitions starting from the ${ }^{4} \mathrm{~A}_{2}^{\prime}(\mathrm{F})$ ground state. However, assuming trigonal bipyramidal geometry around the cobalt ions in $\mathbf{1}\left(\mathrm{CH}_{3} \mathrm{OH}\right)$ and $\mathbf{1}\left(\mathrm{CH}_{3} \mathrm{COCH}_{3}\right)$, the bands in the visible region at $c a .15300$ and $18000 \mathrm{~cm}^{-1}$ are assigned to ${ }^{4} \mathrm{~A}_{2}^{\prime}(\mathrm{F}) \rightarrow{ }^{4} \mathrm{E}^{\prime}(\mathrm{F})$

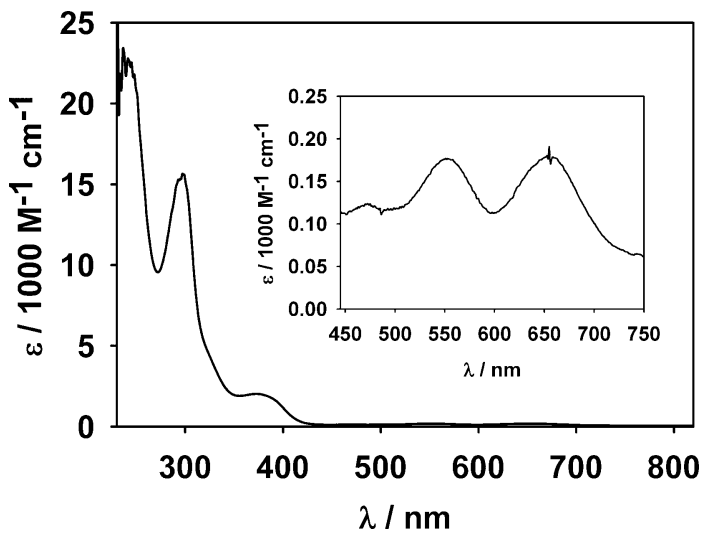

Fig. $9 \mathrm{UV}$-vis spectrum of $\mathbf{1}\left(\mathrm{CH}_{3} \mathrm{COCH}_{3}\right)$ in $\mathrm{CH}_{2} \mathrm{Cl}_{2}$. 
and ${ }^{4} \mathrm{~A}_{2}^{\prime}(\mathrm{F}) \rightarrow{ }^{4} \mathrm{E}^{\prime \prime}(\mathrm{P})$ transitions, respectively. ${ }^{48,123}$ Bimetallic complexes 3 and $\mathbf{3}\left(\mathrm{CH}_{3} \mathrm{OH}\right)$ in methanol exhibit no distinct absorptions above $478 \mathrm{~nm}\left(20900 \mathrm{~cm}^{-1}\right)$ and trimetallic complexes such as 5 (Fig. 10) show poorly resolved $d$ - $d$ bands above $500 \mathrm{~nm}$.

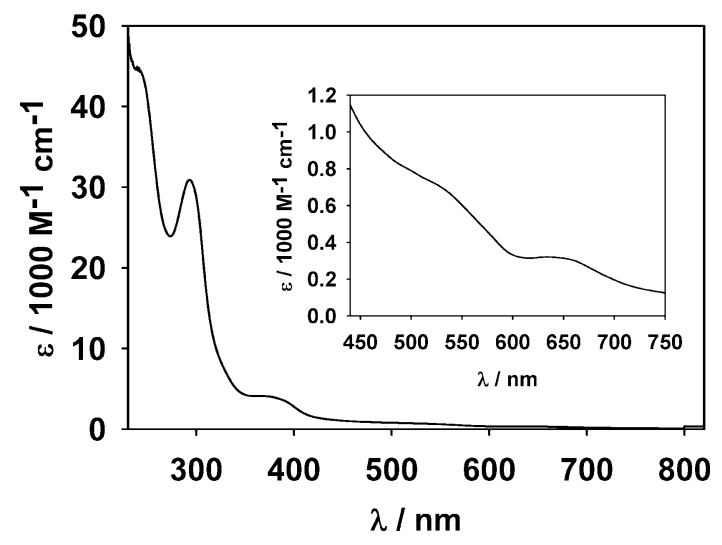

Fig. 10 UV-vis spectrum of 5 in $\mathrm{CH}_{2} \mathrm{Cl}_{2}$.

\section{Magnetic properties}

The magnetic moments for complexes $\mathbf{1}$ to $\mathbf{5}$, obtained either in solution (by Evans' NMR method) or as microcrystalline powder (by SQUID magnetometer), are given in Table 10. Average magnetic moments in the solid state were adjusted for diamagnetic contributions using Pascal's constants and where variable temperature data are presented, the data were fitted in the temperature ranges specified.

The magnetic moments of the monometallic complexes were studied in solution by Evans' method and values are consistent with high spin $\mathrm{Co}^{\mathrm{II}}$ ions $(S=3 / 2)$ in low symmetry environments: $\mathbf{1}\left(\mathrm{CH}_{3} \mathrm{OH}\right), 4.2 \mu_{\mathrm{B}} ; \mathbf{1}\left(\mathrm{CH}_{3} \mathrm{COCH}_{3}\right), 4.4 \mu_{\mathrm{B}} ; \mathbf{1}\left(\mathrm{C}_{3} \mathrm{H}_{6} \mathrm{O}\right), 4.2 \mu_{\mathrm{B}} ; \mathbf{2}$, $3.9 \mu_{\mathrm{B}}$. These values are in the expected range for a high-spin $\mathrm{Co}^{\mathrm{II}}$ $d^{7}$ ion exhibiting significant spin-orbit coupling. The temperature dependence of the effective magnetic moment, $\mu_{\text {eff }}$, for a polycrystalline powder sample of complex $\mathbf{1}\left(\mathrm{CH}_{3} \mathrm{OH}\right)$ was examined (see Figure S2 in Electronic Supplementary Information $\dagger$ ). This fivecoordinate cobalt complex exhibits a magnetic moment of $4.5 \mu_{\mathrm{B}}$ at $300 \mathrm{~K}$, consistent with a $\mathrm{Co}^{\mathrm{II}}$ ion in a high-spin ground state. ${ }^{124}$ This value is larger than the spin-only magnetic moment value of $3.9 \mu_{\mathrm{B}}$ for $S=3 / 2$, indicating significant orbital contributions from low energy excited states typical for high spin $\mathrm{Co}^{\mathrm{II}} .{ }^{125}$ The data can be fit over the whole temperature range studied $(2-300 \mathrm{~K})$ to the Curie-Weiss law. The plot of $\chi_{\mathrm{M}}{ }^{-1}$ versus $T$ reveals a line exhibiting a trend defined by $\chi_{\mathrm{M}}{ }^{-1}=0.4003 T+1.8298\left(R^{2}=\right.$ 0.9999). This gives the Curie constant, $C$, of $2.50 \mathrm{~cm}^{3} \mathrm{~K} \mathrm{~mol}^{-1}$ (resulting in a $g$-value of 2.3) and $\theta=-4.57 \mathrm{~K}$.

Table 10 Effective magnetic moments per Co center for complexes 1-5

\begin{tabular}{llll}
\hline Complex & $\mu_{\text {eff }}$ at $300 \mathrm{~K} / \mu_{\mathrm{B}}$ & Complex & $\mu_{\text {eff }}$ at $300 \mathrm{~K} / \mu_{\mathrm{B}}$ \\
\hline $\mathbf{1}\left(\mathrm{CH}_{3} \mathrm{OH}\right)$ & $4.2^{a}, 4.5^{b}$ & $\mathbf{3}$ & $4.0^{a}, 4.9^{b}$ \\
$\left.\mathbf{1}\left(\mathrm{CH}_{3} \mathrm{COCH}\right)_{3}\right)$ & $4.4^{a}$ & $\mathbf{3}\left(\mathrm{CH}_{3} \mathrm{OH}\right)$ & $1.7^{b}$ \\
$\mathbf{1}\left(\mathrm{C}_{3} \mathrm{H}_{6} \mathrm{O}\right)$ & $4.2^{a}$ & $\mathbf{4}$ & $4.7^{b}$ \\
$\mathbf{2}$ & $3.9^{a}$ & $\mathbf{5}$ & $4.7^{b}$
\end{tabular}

${ }^{a}$ Measured in solution by Evans' method. ${ }^{b}$ Measured in solid state.
The magnetic behaviour of $\mathbf{3}$ expressed as $\chi_{\mathrm{M}}$ and $\mu_{\text {eff }}$ versus $T$ is shown in Fig. 11(a). For the phenolate-bridged dimer 3, the magnetic moment at $300 \mathrm{~K}$ is $6.9 \mu_{\mathrm{B}}$ per mole of dimer $\left(4.9 \mu_{\mathrm{B}}\right.$ per $\mathrm{Co}$ ), which is consistent with two $\mathrm{Co}^{\mathrm{II}}$ ions in the high-spin state $(S=3 / 2)$. The moment decreases as $T$ decreases, but the rate of decrease becomes smaller as it approaches $50 \mathrm{~K}$. Below $50 \mathrm{~K}$, the moment decreases abruptly, reaching a minimum value of $6.3 \mu_{\mathrm{B}}$ per mole of dimer $\left(4.5 \mu_{\mathrm{B}}\right.$ per Co $)$ at $10 \mathrm{~K}$. Below this temperature the moment begins to rise and reaches a maximum of $6.5 \mu_{\mathrm{B}}\left(4.6 \mu_{\mathrm{B}}\right.$ per $\left.\mathrm{Co}\right)$ at $2 \mathrm{~K}$. These variations in magnetic moment over temperature are in fact relatively small, and a plot of $\chi_{\mathrm{M}}{ }^{-1}$ versus $T$ reveals a line consistent with Curie-Weiss behaviour as shown in Fig. 11(b). Applying the Curie-Weiss equation from 2 to $300 \mathrm{~K}$ gives a line defined by $\chi_{\mathrm{M}}{ }^{-1}=0.1706 T+0.6891$ $\left(R^{2}=0.9988\right)$. This gives a Curie constant, $C$, of $5.86 \mathrm{~cm}^{3} \mathrm{~K}$ $\mathrm{mol}^{-1}$ and $\theta=-4.04 \mathrm{~K}$. Because of the dinuclear nature of 3 and its similarity to related phenolate bridged $\mathrm{Co}^{\mathrm{II}}$ dimers of amine bis(phenolate) ligands, ${ }^{47,86}$ the magnetic data for 3 were also modelled using the Heisenberg dimer model considering $S_{\mathrm{A}}=$ $S_{\mathrm{B}}=3 / 2 .{ }^{126}$ Previously reported $\mathrm{Co}^{\mathrm{II}}$ dimers exhibit $\chi_{\mathrm{M}}$ versus $T$ plots possessing maxima at approximately $14 \mathrm{~K}$, consistent with antiferromagnetic interaction where values of $g=2.29$ and $J=$ $-7.5 \mathrm{~cm}^{-1},{ }^{86} g=2.26$ and $J=-4.2 \mathrm{~cm}^{-1},{ }^{46}$ and $g=2.27$ and $J=$ $-6.1 \mathrm{~cm}^{-1}$ (where a zero-field splitting parameter, $D=7.7 \mathrm{~cm}^{-1}$, was
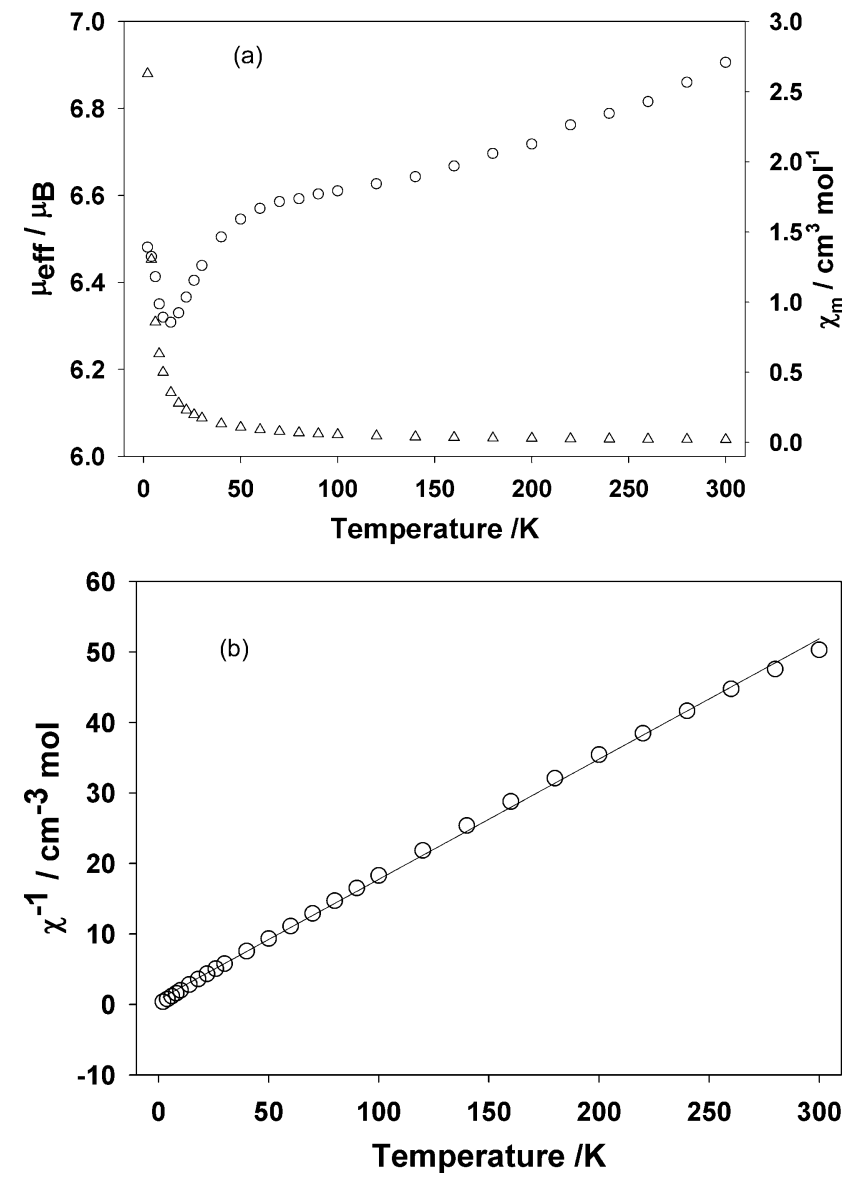

Fig. 11 (a) Magnetic moment $(\bigcirc)$ and susceptibility $(\triangle)$ versus temperature per mole of dimer for 3 . (b) Inverse susceptibility versus temperature plot for 3 . The solid line represents the best fit for the Curie-Weiss model as described in the text. 
also included $)^{47}$ are obtained. Complex 3 shows no maximum over the temperature range examined, thereby implying magnetically isolated $\mathrm{Co}^{\mathrm{II}}$ centers. However, exploring a similar model to that employed in the analogous complexes is warranted. In modelling complex 3 using the Hamiltonian for two $S=3 / 2$ nuclei, the $g$ factor was fixed at 2.3 in agreement with the reported values. To account for the presence of paramagnetic impurity the expression was combined with the Curie law term, $\chi_{\text {para }}=C / T$, according to $\chi_{\mathrm{m}}=[1-P] \chi_{\text {dimer }}+P \chi_{\text {para }}$, where $P$ represents the fraction of paramagnetic $S=3 / 2$ impurity. The presence of temperature independent paramagnetism (TIP) was also included in the model. The resulting best fit of the data yielded negligible values for $J$ $\left(<0.2 \mathrm{~cm}^{-1}\right)$ and $P(<0.01 \%)$. The model does, however, require a large TIP $=36.0 \times 10^{-4} \mathrm{~cm}^{3} \mathrm{~mol}^{-1}$. The best fit between the calculated and experimental data are shown in Figure S3 in the Electronic Supplementary Information. $\dagger$ The resulting small value for $J$ supports the proposal that unlike the previous examples of phenolate-bridged dimeric $\mathrm{Co}^{\mathrm{II}}$ amine-bis(phenolate) complexes, the $\mathrm{Co}^{\mathrm{II}}$ ions in complex $\mathbf{3}$ are magnetically dilute.

The magnetic behaviour of the methanol-bridged dimer, $3\left(\mathrm{CH}_{3} \mathrm{OH}\right)$, expressed as $\chi_{\mathrm{M}}$ and $\mu_{\text {eff }}$ versus $T$ is shown in Fig. 12. $3\left(\mathrm{CH}_{3} \mathrm{OH}\right)$ exhibits a magnetic moment of $2.3 \mu_{\mathrm{B}}$ per mole of dimer $\left(1.7 \mu_{\mathrm{B}}\right.$ per Co). There is a steady decrease in the magnetic moment as temperature decreases, reaching a minimum of $0.84 \mu_{\mathrm{B}}$ per mole of dimer at $2 \mathrm{~K}$. There are two possible interpretations of these data. One is that the data are consistent with two low-spin $\mathrm{Co}^{\text {II }}$ ions $(S=1 / 2)$. The significant decrease in magnetic moment during this temperature range would suggest antiferromagnetic coupling between the two metal ions thus approaching an $S=0$ ground state and/or the presence of zero field splitting. The data were therefore modeled using the Bleaney-Bowers equation, $\chi_{\mathrm{BB}}=\left(N_{A} g^{2} \beta^{2} / k T\right)\left(1+3 \mathrm{e}^{2 J / k T}\right)^{-1}$, for magnetic exchange between two $S=1 / 2$ metal ions. However, this model gave an unreasonably large coupling constant, $J=$ $-490 \mathrm{~cm}^{-1}$ and required a very large contribution from temperature independent paramagnetism, TIP $=21.0 \times 10^{-4} \mathrm{~cm}^{3} \mathrm{~mol}^{-1}$. Furthermore, zero-field splitting (ZFS) was not included in this model, and ZFS is qualitatively similar to an antiferromagnetic interdimer interaction and typically large for Co ions. ${ }^{127}$ The low room-temperature moment and strong temperature dependence may also be explained if the cobalt centers are intermediate spin $\mathrm{Co}^{\mathrm{III}}$ with a low lying $S=1$ state. The higher oxidation

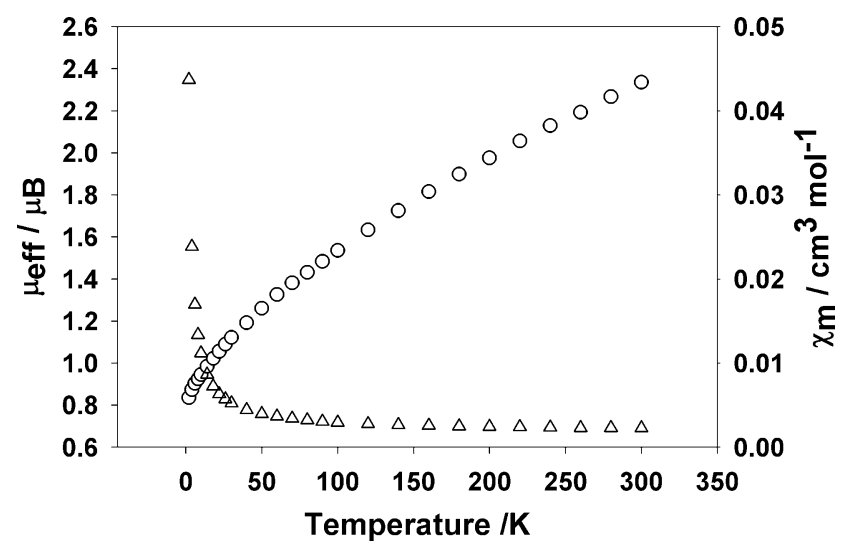

Fig. 12 Magnetic moment $(\bigcirc)$ and susceptibility $(\triangle)$ versus temperature per mole of dimer for $\mathbf{3}\left(\mathrm{CH}_{3} \mathrm{OH}\right)$. state is consistent with the shorter bond lengths compared to monomeric $\mathrm{Co}^{\mathrm{II}}$ complexes described herein and elsewhere (see above). Intermediate spin $\mathrm{Co}^{\mathrm{III}}$ ions are rare but typically found in five-coordinate (trigonal bipyramidal and square pyramidal) geometries ${ }^{128-131}$ whereas octahedral complexes are almost always low spin. However, given the structural and magnetochemical behavior exhibited by $3\left(\mathrm{CH}_{3} \mathrm{OH}\right)$, the assignment of $S=1$ spinstates to the Co ions in the dimer cannot be excluded.

A polycrystalline sample of trimetallic $\mathbf{4}$ exhibits a magnetic moment of $8.0 \mu_{\mathrm{B}}$ per molecule $\left(4.7 \mu_{\mathrm{B}}\right.$ per Co), which is within the expected range for high spin $(S=3 / 2) \mathrm{Co}^{\mathrm{II}}$ ions exhibiting strong spin-orbit coupling. ${ }^{125,127}$ Cooling the sample causes a steadily more rapid decrease in moment reaching $6.5 \mu_{\mathrm{B}}$ per molecule at $4 \mathrm{~K}$ (Fig. 13). The shape of this curve is typical of polynuclear $\mathrm{Co}^{\mathrm{II}}$ species, and is expected to include contributions from zero-field splitting of the $\mathrm{Co}^{\mathrm{II}}$ and weak antiferromagnetic exchange within the chain. The data obey the Curie-Weiss law throughout the temperature range studied, with $g=2.45$ and $\theta=-6.81 \mathrm{~K}$ (Figure S4 in Electronic Supplementary Information $\uparrow$ ). The magnetic data for 4 were modelled by the isotropic trimer model where $S=$ $3 / 2 .{ }^{132}$ The best fit obtained generated $g=2.28$, an exceedingly weak antiferromagnetic exchange with $J=-0.07 \mathrm{~cm}^{-1}$ and Weiss constant $\theta=-4.65$. The presence of TIP was included to improve the fit, where TIP $=21.0 \times 10^{-4} \mathrm{~cm}^{3} \mathrm{~mol}^{-1}$. For simplicity, ZFS was excluded from the model.

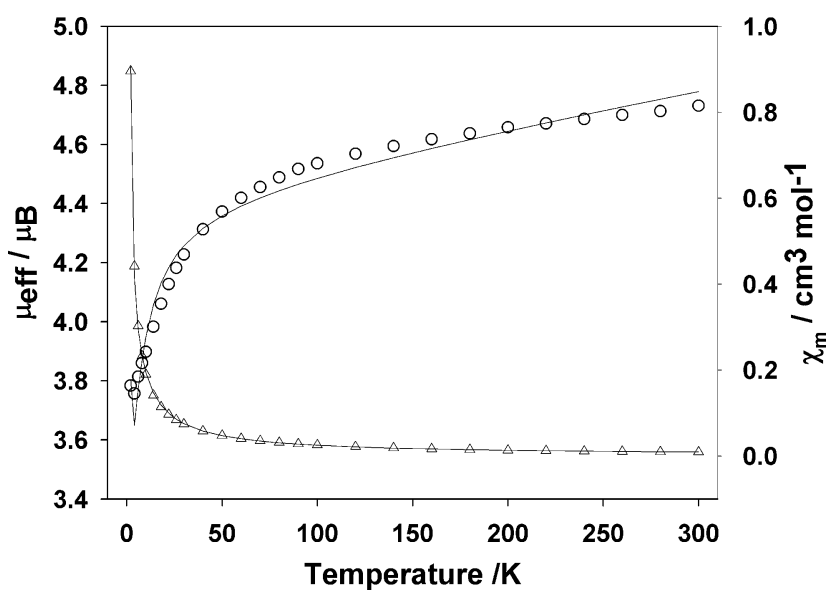

Fig. 13 Magnetic moment $(\bigcirc)$ and susceptibility $(\triangle)$ versus temperature per Co atom for $\mathbf{4}$. The solid lines represent the fit given in the text.

The related trimetallic complex, $\mathbf{5}$, exhibits similar magnetic behaviour to 4 . Plots of $\chi_{\mathrm{M}}$ and $\mu_{\text {eff }}$ versus $T$ per Co atom are shown in Fig. 14. A $300 \mathrm{~K}$ magnetic moment of $4.7 \mu_{\mathrm{B}}$ is similar to that observed for $\mathbf{4}$. The moment decreases more rapidly as temperature is lowered and achieves a local minimum of $3.7 \mu_{\mathrm{B}}$ at $30 \mathrm{~K}$ before rising and falling to a low temperature limit of $2.4 \mu_{\mathrm{B}}$ at $2 \mathrm{~K}$, consistent with significant zero-field splitting. Again, the absence of a maximum $\chi$ in the plot is indicative of very weak or no antiferromagnetic exchange between $\mathrm{Co}^{\text {II }}$ ions. It obeys the Curie-Weiss law giving $g=2.44$ and $\theta=-18.29 \mathrm{~K}$ (see Figure S5 in Electronic Supplementary Information). Modelling these data was performed as for compound $\mathbf{4}$ resulting in the following parameters: $g=2.01, J=-0.03 \mathrm{~cm}^{-1}, \theta=-5.25 \mathrm{~K}$ and TIP $=$ $32.0 \times 10^{-4} \mathrm{~cm}^{3} \mathrm{~mol}^{-1}$. The variation in $g$-values obtained using the two models is observed in the deviation of each model from 


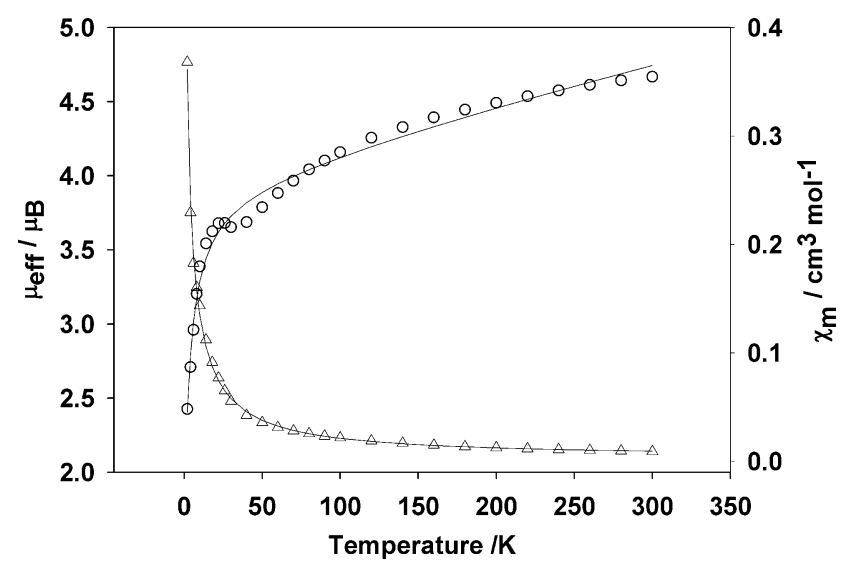

Fig. 14 Magnetic moment $(\bigcirc)$ and susceptibility $(\triangle)$ versus temperature per $\mathrm{Co}$ atom for $\mathbf{5}$. The solid lines represent the fit given in the text.

the experimental data for both $\mathbf{4}$ and $\mathbf{5}$. The Curie-Weiss model provided a superior fit to the $\mu_{\text {eff }}$ data at higher temperatures, whereas the isotropic linear trimer reproduces these data better at lower temperatures. Interpretation of magnetic susceptibility data from polynuclear, high-spin $\mathrm{Co}^{\mathrm{II}}$ species is complicated by the coexistence of weak superexchange $\left(|J|<20 \mathrm{~cm}^{-1}\right),{ }^{125}$ strong zero-field splitting (ZFS, $|D|>20 \mathrm{~cm}^{-1}$ ), very large $g$-factor anisotropy ${ }^{133}$ and that the parameters $J$ and $D$ are often of a similar magnitude. ${ }^{134}$ The absence of a maximum in the susceptibility combined with strong spin-orbit coupling effects means a more elaborate treatment of the data is needed. ${ }^{135}$

\section{Electrochemical studies}

Electrochemistry experiments were carried out using a threecompartment electrochemical cell, consisting of a platinum counter electrode, saturated calomel reference electrode (SCE) and a glassy carbon working electrode. Complexes $\mathbf{1}, \mathbf{1}\left(\mathrm{CH}_{3} \mathrm{OH}\right)$, 4, and 5, along with the metal-free ligand precursor, $\mathrm{H}_{2}\left[\mathrm{O}_{2} \mathrm{NN}^{\prime}\right]^{\text {BuBuNMe2}}$, were investigated by cyclic voltammetry $(\mathrm{CV})$ in $\mathrm{CH}_{2} \mathrm{Cl}_{2}$ solutions containing $0.1 \mathrm{M}\left[(n-\mathrm{Bu})_{4} \mathrm{~N} \mathrm{PF}_{6}\right.$ as electrolyte. Results are summarized in Table 11 and representative cyclic voltammograms of $\mathbf{1}\left(\mathrm{CH}_{3} \mathrm{OH}\right)$ and $\mathbf{5}$ are shown in Fig. 15 and 16. Voltammograms of $\mathbf{1}, \mathbf{4}$ and $\mathrm{H}_{2}\left[\mathrm{O}_{2} \mathrm{NN}^{\prime}\right]^{\mathrm{BuBuNMe2}}$ are given in Figures S6 to S8 in the Electronic Supplementary Information. $\dagger$ All experiments were performed at a scan rate of $100 \mathrm{mV} \mathrm{s}^{-1}$. No redox events were observed at negative potential for any of the compounds investigated, therefore only events occurring at positive potentials are discussed.

Table 11 Half wave potentials for oxidation of $\mathrm{Co}^{\mathrm{II}}$ complexes and $\mathrm{H}_{2}\left[\mathrm{O}_{2} \mathrm{NN}^{\prime}\right]^{\text {BuBuNMe2 }}$

\begin{tabular}{lll}
\hline Compound & $\mathrm{E}_{2}{ }^{\mathrm{ox}} / \mathrm{V}$ & $\mathrm{E}_{1}{ }^{\mathrm{ox}} / \mathrm{V}$ \\
\hline $\mathbf{1}$ & $1.02^{a}$ & $0.62^{a}$ \\
$\mathbf{1}\left(\mathrm{CH}_{3} \mathrm{OH}\right)$ & $0.91^{a, c}$ & $0.60^{a}$ \\
$\mathbf{4}$ & $1.43^{a, c}$ & $0.85^{a}$ \\
$\mathbf{5}$ & $1.34^{a}$ & $0.71^{a}$ \\
$\mathrm{H}_{2}\left[\mathrm{O}_{2} \mathrm{NN}^{\prime}\right]^{\mathrm{BuBu}}$ & $1.25^{b}$ & $0.68^{a}$
\end{tabular}

${ }^{a}$ Quasi-reversible reaction. ${ }^{b}$ Irreversible reaction, $\mathrm{E}_{1 / 2}$ value estimated. ${ }^{c}$ Reduction waves possess a slight shoulder.

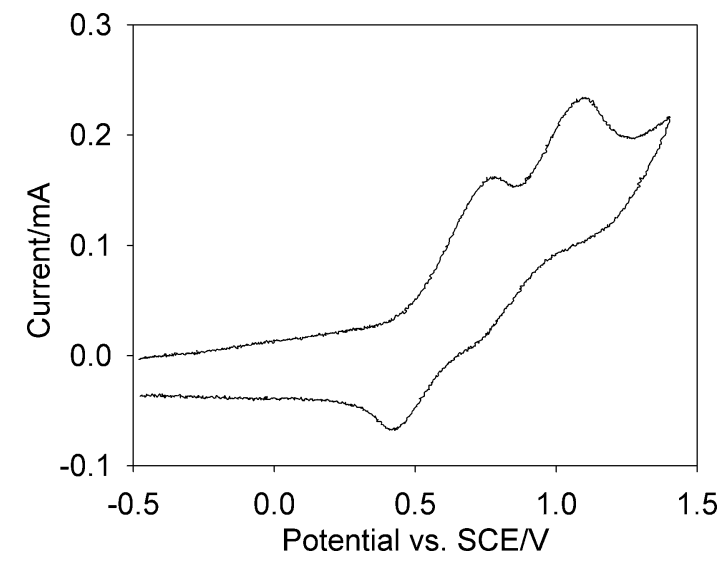

Fig. 15 Cyclic voltammogram of $\mathbf{1}\left(\mathrm{CH}_{3} \mathrm{OH}\right)$ in $\mathrm{CH}_{2} \mathrm{Cl}_{2} \quad(0.1 \mathrm{M}$ $\left.\left[(n-\mathrm{Bu})_{4} \mathrm{~N}\right] \mathrm{PF}_{6}\right)$ at $20{ }^{\circ} \mathrm{C}$ and a scan rate of $100 \mathrm{mV} \mathrm{s}^{-1}$.

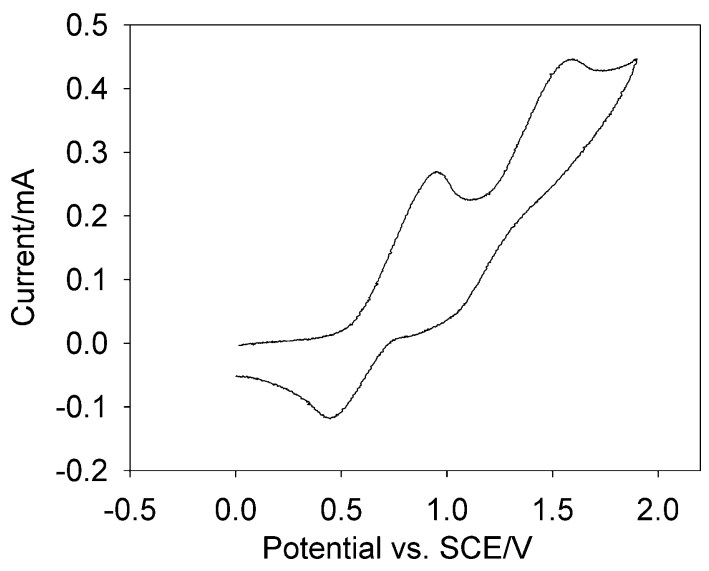

Fig. 16 Cyclic voltammogram of 5 in $\mathrm{CH}_{2} \mathrm{Cl}_{2}\left(0.1 \mathrm{M}\left[(n-\mathrm{Bu})_{4} \mathrm{~N}\right] \mathrm{PF}_{6}\right)$ at $20^{\circ} \mathrm{C}$ and a scan rate of $100 \mathrm{mV} \mathrm{s}^{-1}$.

Monometallic complexes $\mathbf{1}$ and $\mathbf{1}\left(\mathrm{CH}_{3} \mathrm{OH}\right)$ exhibit quasireversible oxidative responses $\left(\mathrm{E}_{1}{ }^{\mathrm{Ox}}\right)$ at +0.62 and $+0.60 \mathrm{~V}$, respectively. These signals may be attributed to ligand oxidation (phenolate/phenoxyl radical), however, metal-centered oxidation assigned to a $\mathrm{Co}^{\mathrm{II}} / \mathrm{Co}^{\mathrm{III}}$ redox process has also been suggested for related cobalt(II) amino-phenolate complexes showing oxidation waves at similar potentials. ${ }^{136}$ Additional quasi-reversible oxidation waves $\left(\mathrm{E}_{2}{ }^{\mathrm{Ox}}\right)$ are observed at +1.02 and $+0.91 \mathrm{~V}$ for 1 and $\mathbf{1}\left(\mathrm{CH}_{3} \mathrm{OH}\right)$, respectively, which are proposed to be ligand-centred redox processes. To further investigate whether the observed redox behaviour at the $\mathrm{E}_{1}{ }^{\mathrm{ox}}$ potentials is indeed ligand centered, cyclic voltammetry was conducted on the unmetallated protioligand, $\mathrm{H}_{2}\left[\mathrm{O}_{2} \mathrm{NN}^{\prime}\right]^{\text {BuBuNMe2 }}$. The ligand exhibits a quasireversible oxidation wave at $+0.68 \mathrm{~V}$ and irreversible reaction estimated at $+1.25 \mathrm{~V}$. In light of the similar $\mathrm{E}_{1}{ }^{\mathrm{ox}}$ potentials for both the complexes and the unmetallated ligand, it is most likely that these oxidation processes are indeed ligand-based.

The trimetallic complexes also exhibit two oxidation waves. 4 shows quasi-reversible responses at +0.85 and $+1.43 \mathrm{~V}$, whereas $\mathbf{5}$ shows quasi-reversible events at +0.71 and at $+1.34 \mathrm{~V}$. These redox events occur at significantly different potentials to those observed for the monometallic complexes and the unmetallated ligand. It is possible that metal-centered $\left(\mathrm{Co}^{\mathrm{II}} / \mathrm{Co}^{\text {III }}\right)$ redox may be occurring at one of the $\mathrm{Co}^{\mathrm{II}}$ ions in the trimetallic molecules, particularly since 
the central $\mathrm{Co}^{\mathrm{II}}$ ion is coordinated to six ligands in monodentate fashion and ligand loss is therefore more facile than for the terminal, five-coordinate $\mathrm{Co}^{\mathrm{II}}$ ions bearing the tetradentate ligands. As a result, geometric distortions caused by oxidation/spin-state changes at the metal centre may be more easily accommodated. Trimetallic complexes possessing linear $\mathrm{Co}^{\mathrm{II}}-\mathrm{Co}^{\mathrm{II}}-\mathrm{Co}^{\mathrm{II}}$ and $\mathrm{Co}^{\mathrm{III}}-$ $\mathrm{Co}^{\mathrm{II}}-\mathrm{Co}^{\mathrm{III}}$ arrangements have been reported, ${ }^{45}$ however, for those examples where cyclic voltammetry studies were performed, both metal- and ligand-based redox processes were proposed.

\section{Conclusion}

In summary, we report the synthesis and structure of new diaminebis(phenolate) cobalt complexes, and their electronic, magnetic and electrochemical behaviour. Monomeric $\mathrm{Co}^{\mathrm{II}}$ complexes are obtained when the pendant neutral donor of the ligand is a tertiary amine. A four coordinate, trigonal monopyramidal complex is obtained if recrystallized in a hydrocarbon solvent. In the presence of donor solvents, trigonal bipyramidal complexes are obtained. All of the monomeric species possess high-spin cobalt centers. When the tetradentate ligand possesses a pyridyl pendant donor, dimeric cobalt complexes are obtained. A fivecoordinate phenolate-bridged dimer is obtained in the absence of a coordinating solvent. However, in the presence of methanol, this complex exhibits a dimeric structure with the Co centers bridged by two methanol/methoxide molecules. This contrasts with the monomeric solvento adducts formed with tertiary amine pendant-containing ligands. As for the monomers described, the phenolate-bridged dimer possesses magnetically dilute high-spin cobalt ions. The methanol-bridged dimer, on the other hand, is best described as either low-spin $d^{7}$ or intermediate-spin $(S=1)$ $d^{6}$. Lastly, it was found that when the ratio of Co to ligand was greater than $1: 1$, trimetallic compounds were obtained. In these species, the two terminal cobalt ions are decorated by the diaminebis(phenolate) ligands. These metals are bridged to the central metal centre by acetate ligands. The octahedral coordination sphere of the central ion is completed by four methanol ligands. The $\mathrm{Co}^{\mathrm{II}}$ centers in these compounds are all high-spin and show only weak antiferromagnetic exchange when modelled as a linear isotropic trimer. The diversity of coordination complexes obtained when very subtle variations in the synthetic procedures are employed is a testament to the versatility and tunability of diamine-bis(phenolate) ligands.

\section{Acknowledgements}

We thank Dr Laurence K. Thompson and Dr Konstantin Shuvaev for valuable discussions and acquisition of magnetic data. We thank NSERC of Canada (Discovery Grants and Research Tools and Instrument Grants to F. M. K. and C. M. K.; Undergraduate Student Research Awards to J. B. and C. F. P.), Canada Foundation for Innovation (Leaders' Opportunity Fund Awards to F. M. K. and C. M. K.), the Provincial Government of Newfoundland and Labrador (IRIF grants to F. M. K. and C. M. K.), and Memorial University (Undergraduate Research Support to C. F., Graduate Studies Scholarship to U. K. D.) for generous financial support. The Inorganic Chemistry Exchange (ICE) Program of the Division of Inorganic Chemistry, Chemical Institute of Canada, is thanked for facilitating aspects of this research (J. B. and F. M. K.).

\section{Notes and References}

1 A. Cohen, A. Yeori, J. Kopilov, I. Goldberg and M. Kol, Chem. Commun., 2008, 2149-2151.

2 S. Gendler, S. Groysman, Z. Goldschmidt, M. Shuster and M. Kol, J. Polym. Sci., Part A: Polym. Chem., 2006, 44, 1136-1146.

3 S. Gendler, S. Segal, I. Goldberg, Z. Goldschmidt and M. Kol, Inorg. Chem., 2006, 45, 4783-4790.

4 S. Groysman, E. Y. Tshuva, D. Reshef, S. Gendler, I. Goldberg, M. Kol, Z. Goldschmidt, M. Shuster and G. Lidor, Isr. J. Chem., 2002, 42, 373-381.

5 S. Groysman, I. Goldberg, M. Kol, E. Genizi and Z. Goldschmidt, Organometallics, 2003, 22, 3013-3015.

6 E. Y. Tshuva, S. Groysman, I. Goldberg, M. Kol and Z. Goldschmidt, Organometallics, 2002, 21, 662-670.

7 E. Y. Tshuva, I. Goldberg, M. Kol and Z. Goldschmidt, Organometallics, 2001, 20, 3017-3028.

8 E. Y. Tshuva, M. Versano, I. Goldberg, M. Kol, H. Weitman and Z. Goldschmidt, Inorg. Chem. Commun., 1999, 2, 371-373.

9 A. Yeori, I. Goldberg and M. Kol, Macromolecules, 2007, 40, 85218523.

10 A. J. Chmura, M. G. Davidson, M. D. Jones, M. D. Lunn, M. F. Mahon, A. F. Johnson, P. Khunkamchoo, S. L. Roberts and S. S. F. Wong, Macromolecules, 2006, 39, 7250-7257.

11 S. Groysman, E. Sergeeva, I. Goldberg and M. Kol, Inorg. Chem., 2005, 44, 8188-8190.

12 D. T. Dugah, B. W. Skelton and E. E. Delbridge, Dalton Trans., 2009, $1436-1445$.

13 Z. Zhang, X. Xu, W. Li, Y. Yao, Y. Zhang, Q. Shen and Y. Luo, Inorg. Chem., 2009, 48, 5715-5724.

14 H. E. Dyer, S. Huijser, A. D. Schwarz, C. Wang, R. Duchateau and P. Mountford, Dalton Trans., 2008, 32-35.

15 C. E. Willans, M. A. Sinenkov, G. K. Fukin, K. Sheridan, J. M. Lynam, A. A. Trifonov and F. M. Kerton, Dalton Trans., 2008, 3592-3598.

16 E. E. Delbridge, D. T. Dugah, C. R. Nelson, B. W. Skelton and A. H. White, Dalton Trans., 2007, 143-153.

17 H. Zhou, H. Guo, Y. Yao, L. Zhou, H. Sun, H. Sheng, Y. Zhang and Q. Shen, Inorg. Chem., 2007, 46, 958-964.

18 A. Amgoune, C. M. Thomas, T. Roisnel and J. F. Carpentier, Chem.Eur. J., 2006, 12, 169-179.

19 F. Bonnet, A. R. Cowley and P. Mountford, Inorg. Chem., 2005, 44, 9046-9055.

20 C. L. Boyd, T. Toupance, B. R. Tyrrell, B. D. Ward, C. R. Wilson, A. R. Cowley and P. Mountford, Organometallics, 2005, 24, 309330.

21 C. Cai, A. Abderramane, C. W. Lehmann and J. Carpentier, Chem. Commun., 2004, 330.

22 F. M. Kerton, A. C. Whitwood and C. E. Willans, Dalton Trans., 2004, 2237-2244.

23 S. Ito, S. Nishino, H. Itoh, S. Ohba and Y. Nishida, Polyhedron, 1998, 17, 1637-1642.

24 I. A. Koval, M. Huisman, A. F. Stassen, P. Gamez, M. Lutz, A. L. Spek and J. Reedijk, Eur. J. Inorg. Chem., 2004, 591-600.

25 T. Nagataki and S. Itoh, Chem. Lett., 2007, 36, 748-749.

26 M. M. Olmstead, T. E. Patten and C. Troeltzsch, Inorg. Chim. Acta, 2004, 357, 619-624.

27 A. Philibert, F. Thomas, C. Philouze, S. Hamman, E. Saint-Aman and J. L. Pierre, Chem.-Eur. J., 2003, 9, 3803-3812.

28 N. Reddig, D. Pursche, M. Kloskowski, C. Slinn, S. M. Baldeau and A. Rompel, Eur. J. Inorg. Chem., 2004, 879-887.

29 N. Reddig, D. Pursche, B. Krebs and A. Rompel, Inorg. Chim. Acta, 2004, 357, 2703-2712.

30 N. Reddig, D. Pursche and A. Rompel, Dalton Trans., 2004, 1474 1480.

31 M. S. Shongwe, C. H. Kaschula, M. S. Adsetts, E. W. Ainscough, A. M. Brodie and M. J. Morris, Inorg. Chem., 2005, 44, 3070-3079.

32 T. Weyhermuller, T. K. Paine, E. Bothe, E. Bill and P. Chaudhuri, Inorg. Chim. Acta, 2002, 337, 344-356.

33 R. K. Dean, S. L. Granville, L. N. Dawe, A. Decken, K. M. Hattenhauer and C. M. Kozak, Dalton Trans., 2010, 39, 548-559.

34 P. Mialane, E. Anxolabehere-Mallart, G. Blondin, A. Nivorojkine, J. Guilhem, L. Tchertanova, M. Cesario, N. Ravi, E. Bominaar, J. J. Girerd and E. Munck, Inorg. Chim. Acta, 1997, 263, 367-378.

35 R. Viswanathan, M. Palaniandavar, T. Balasubramanian and T. P. Muthiah, Inorg. Chem., 1998, 37, 2943-2951. 
36 M. Velusamy, M. Palaniandavar, R. S. Gopalan and G. U. Kulkarni, Inorg. Chem., 2003, 42, 8283-8293.

37 M. Velusamy, R. Mayilmurugan and M. Palaniandavar, Inorg. Chem., 2004, 43, 6284-6293.

38 M. Merkel, F. K. Muller and B. Krebs, Inorg. Chim. Acta, 2002, 337, 308-316.

39 M. Lanznaster, H. P. Hratchian, M. J. Heeg, L. M. Hryhorczuk, B. R. McGarvey, H. B. Schlegel and C. N. Verani, Inorg. Chem., 2006, 45, 955-957.

40 K. Hasan, C. Fowler, P. Kwong, A. K. Crane, J. L. Collins and C. M. Kozak, Dalton Trans., 2008, 2991-2998.

41 J. Hwang, K. Govindaswamy and S. A. Koch, Chem. Commun., 1998, 1667-1668.

42 E. Safaei, T. Weyhermueller, E. Bothe, K. Wieghardt and P. Chaudhuri, Eur. J. Inorg. Chem., 2007, 2334-2344.

43 S. Sarkar, A. Mondal, J. Ribas, M. G. B. Drew, K. Pramanik and K. K. Rajak, Eur. J. Inorg. Chem., 2004, 4633-4639.

44 R. R. Chowdhury, A. K. Crane, C. Fowler, P. Kwong and C. M. Kozak, Chem. Commun., 2008, 94-96.

45 S. Banerjee, J.-T. Chen and C.-Z. Lu, Polyhedron, 2007, 26, 686-694.

46 E. Labisbal, L. Rodriguez, O. Souto, A. Sousa-Pedrares, J. A. GarciaVazquez, J. Romero, A. Sousa, M. Yanez, F. Orallo and J. A. Real, Dalton Trans., 2009, 8644-8656.

47 A. Mukherjee, F. Lloret and R. Mukherjee, Inorg. Chem., 2008, 47, 4471-4480.

48 D. Schnieders, A. Hammerschmidt, M. Merkel, F. Schweppe and B. Krebs, Z. Anorg. Allg. Chem., 2008, 634, 2933-2939.

49 W. Ren, Z. Liu, Y. Wen, R. Zhang and X. Lu, J. Am. Chem. Soc., 2009, 131, 11509-11518.

50 D. J. Darensbourg and A. I. Moncada, Macromolecules, 2009, 42, 4063-4070.

51 C. T. Cohen and G. W. Coates, J. Polym. Sci., Part A: Polym. Chem., 2006, 44, 5182-5191.

52 C. T. Cohen, C. M. Thomas, K. L. Peretti, E. B. Lobkovsky and G. W. Coates, Dalton Trans., 2006, 237-249.

53 C. T. Cohen, T. Chu and G. W. Coates, J. Am. Chem. Soc., 2005, 127, 10869-10878.

54 Z. Q. Qin, C. M. Thomas, S. Lee and G. W. Coates, Angew. Chem., Int. Ed., 2003, 42, 5484-5487.

55 W. Hirahata, R. M. Thomas, E. B. Lobkovsky and G. W. Coates, J. Am. Chem. Soc., 2008, 130, 17658-17659.

56 H. Ajiro, K. L. Peretti, E. B. Lobkovsky and G. W. Coates, Dalton Trans., 2009, 8828-8830.

57 K. L. Peretti, H. Ajiro, C. T. Cohen, E. B. Lobkovsky and G. W. Coates, J. Am. Chem. Soc., 2005, 127, 11566-11567.

58 J. Muller, C. Wurtele, O. Walter and S. Schindler, Angew. Chem., Int. Ed., 2007, 46, 7775-7777.

59 A. Shaabani, E. Farhangi and A. Rahmati, Appl. Catal., A, 2008, 338, 14-19.

60 A. Shaabani, A. H. Rezayan, M. Heidary and A. Sarvary, Catal. Commun., 2008, 10, 129-131.

61 F. M. Kerton, S. Holloway, A. Power, R. G. Soper, K. Sheridan, J. M. Lynam, A. C. Whitwood and C. E. Willans, Can. J. Chem., 2008, 86, 435-443.

62 K. L. Collins, L. J. Corbett, S. M. Butt, G. Madhurambal and F. M. Kerton, Green Chem. Lett. Rev., 2007, 1, 31-35.

63 E. Y. Tshuva, I. Goldberg, M. Kol, H. Weitman and Z. Goldschmidt, Chem. Commun., 2000, 379-380.

64 Y. Sarazin, R. H. Howard, D. L. Hughes, S. M. Humphrey and M. Bochmann, Dalton Trans., 2006, 340-350.

65 M. D. Eelman, J. M. Blacquiere, M. M. Moriarty and D. E. Fogg, Angew. Chem., Int. Ed., 2008, 47, 303-306.

66 N. Ikpo, S. M. Butt, K. L. Collins and F. M. Kerton, Organometallics, 2009, 28, 837-842.

67 J. W. Pflugrath, Acta Crystallogr., Sect. D: Biol. Crystallogr., 1999, 55, $1718-1725$.

68 A. Altomare, G. Cascarano, C. Giacovazzo, A. Guagliardi, M. Burla, G. Polidori and M. Camalli, J. Appl. Crystallogr., 1994, 27, 435.

69 P. T. Beurskens, G. Admiraal, G. Beurskens, W. P. Bosman, S. GarciaGranda, R. O. Gould, J. M. M. Smits, C. Smykalla, 'The DIRDIF program system', Technical Report of the Crystallography Laboratory, University of Nijmegen, Netherlands, 1992.

70 P. T. Beurskens, G. Admiraal, G. Beurskens, W. P. Bosman, R. de Gelder, R. Israel, J. M. M. Smits, 'DIRDIF99', University of Nijmegen, Netherlands, 1999.
71 A. L. Spek, J. Appl. Crystallogr., 2003, 36, 7-13.

72 D. T. Cromer, J. T. Waber, "International Tables for X-ray Crystallography", Vol. IV, The Kynoch Press: Birmingham, UK, 1974.

73 J. A. Ibers and W. C. Hamilton, Acta Crystallogr., 1964, 17, 781-782.

74 D. C. Creagh, W. J. McAuley, "International Tables for Crystallography", Vol C, ed. A.J.C. Wilson, Kluwer Academic Publishers: Boston, 1992, 219-222.

75 D. C. Creagh, J. H. Hubbell, "International Tables for Crystallography", Vol C, ed. A.J.C. Wilson, Kluwer Academic Publishers: Boston, 1992, 200-206.

76 CrystalStructure 3.7.0: Crystal Structure Analysis Package, Rigaku and Rigaku/MSC, The Woodlands, Texas, 2000-2005.

77 D. J. Watkin, C. K. Prout, J. R. Carruthers, P. W. Betteridge, CRYSTALS Issue 10, Chemical Crystallography Laboratory: Oxford, UK, 1996.

78 G. M. Sheldrick CELL_NOW, Bruker AXS, Inc.: Madison, Wisconsin, 2005.

79 SAINT 7.23A, Bruker AXS Inc.: Madison, Wisconsin, 2006.

80 G. M. Sheldrick TWINABS 1.05, Bruker Nonius, Inc.: Madison, Wisconsin, 2004.

81 G. M. Sheldrick SADABS 2004, Bruker AXS, Inc.: Madison, Wisconsin, USA. 2004.

82 G. M. Sheldrick, Acta Cryst., 2008, A64, 112-122.

83 A. W. Addison, T. N. Rao, J. Reedijk, J. Vanrijn and G. C. Verschoor, J. Chem. Soc., Dalton Trans., 1984, 1349-1356.

84 I. J. Bruno, J. C. Cole, M. Kessler, J. Luo, W. D. S. Motherwell, L. H. Purkis, B. R. Smith, R. Taylor, R. I. Cooper, S. E. Harris and A. G. Orpen, J. Chem. Inf. Comput. Sci., 2004, 44, 2133-2144.

85 S. L. Holt, R. DeIasi and B. Post, Inorg. Chem., 1971, 10, 1498-1500.

86 L. Rodriguez, E. Labisbal, A. Sousa-Pedrares, J. Garcia-Vazquez, J. Romero, M. L. Duran, J. A. Real and A. Sousa, Inorg. Chem., 2006, 45, 7903-7914.

87 E. Solari, C. Floriani, D. Cunningham, T. Higgins and P. McArdle, J. Chem. Soc., Dalton Trans., 1991, 3139-3143.

88 A. R. F. Cox, V. C. Gibson, E. L. Marshall, A. J. P. White and D. Yeldon, Dalton Trans., 2006, 5014-5023.

89 M. Mikuriya, N. Nagao and K. Kundo, Chem. Lett., 2000, 516-517.

90 L. Vaiana, C. Platas-Iglesias, D. Esteban-Gomez, F. Avecilla, J. M. Clemente-Juan, J. A. Real, A. de Blas and T. Rodriguez-Blas, Dalton Trans., 2005, 2031-2037.

91 K. Matsumoto, N. Sekine, K. Arimura, M. Ohba, H. Sakiyama and H. Okawa, Bull. Chem. Soc. Jpn., 2004, 77, 1343-1351.

92 T. J. Mizoguchi, J. Kuzelka, B. Spingler, J. L. DuBois, R. M. Davydov, B. Hedman, K. O. Hodgson and S. J. Lippard, Inorg. Chem., 2001, 40, 4662-4673.

93 A. Diebold, A. Elbouadili and K. S. Hagen, Inorg. Chem., 2000, 39, 3915-3923.

94 K. S. Hagen, R. Lachicotte and A. Kitaygorodskiy, J. Am. Chem. Soc., 1993, 115, 12617-12618.

95 M. M. Olmstead, P. P. Power and G. A. Sigel, Inorg. Chem., 1988, 27, $580-583$.

96 D. J. Darensbourg, M. W. Holtcamp, B. Khandelwal, K. K. Klausmeyer and J. H. Reibenspies, J. Am. Chem. Soc., 1995, 117, 538-539.

97 H. V. R. Dias and Z. Y. Wang, Inorg. Chem., 2000, 39, 3724 3727.

98 D. J. Darensbourg, J. R. Wildeson, S. J. Lewis and J. C. Yarbrough, J. Am. Chem. Soc., 2002, 124, 7075-7083.

99 D. J. Darensbourg, D. R. Billodeaux and L. M. Perez, Organometallics, 2004, 23, 5286-5290.

100 P. Chen, M. H. Chisholm, J. C. Gallucci, X. Y. Zhang and Z. P. Zhou, Inorg. Chem., 2005, 44, 2588-2595.

101 M. B. Jones and C. E. MacBeth, Inorg. Chem., 2007, 46, 8117-8119.

102 R. L. Lucas, M. K. Zart, J. Murkerjee, T. N. Sorrell, D. R. Powell and A. S. Borovik, J. Am. Chem. Soc., 2006, 128, 15476-15489.

103 M. Ray, B. S. Hammes, G. P. A. Yap, A. L. Rheingold and A. S. Borovik, Inorg. Chem., 1998, 37, 1527-1532.

104 L. Sacconi, A. Orlandini and S. Midollini, Inorg. Chem., 1974, 13, $2850-2859$.

105 C. C. Cummins, J. Lee, R. R. Schrock and W. D. Davis, Angew. Chem., Int. Ed. Engl., 1992, 31, 1501-1503.

106 C. C. Cummins, R. R. Schrock and W. M. Davis, Inorg. Chem., 1994, 33, 1448-1457.

107 M. Ray, G. P. A. Yap, A. L. Rheingold and A. S. Borovik, J. Chem. Soc., Chem. Commun., 1995, 1777-1778. 
108 M. Ray, A. P. Golombek, M. P. Hendrich, V. G. Young and A. S. Borovik, J. Am. Chem. Soc., 1996, 118, 6084-6085.

109 C. Rosenberger, R. R. Schrock and W. M. Davis, Inorg. Chem., 1997, 36, 123-125.

110 N. Emig, H. Nguyen, H. Krautscheid, R. Reau, J. B. Cazaux and G. Bertrand, Organometallics, 1998, 17, 3599-3608.

111 T. Agapie, A. L. Odom and C. C. Cummins, Inorg. Chem., 2000, 39, 174-179.

112 S. Schneider and A. C. Filippou, Inorg. Chem., 2001, 40, 4674-4677.

113 A. C. Filippou, S. Schneider and G. Schnakenburg, Inorg. Chem., 2003, 42, 6974-6976.

114 F. Gross and H. Vahrenkamp, Inorg. Chem., 2005, 44, 3321-3329.

115 G. Brewer, C. Brewer, G. White, R. J. Butcher, C. Viragh, E. E. Carpenter and A. Schmiedekamp, Inorg. Chim. Acta, 2009, 362, 41584166.

116 R. R. Holmes, Acc. Chem. Res., 1979, 12, 257-265.

117 A. Gerli, K. S. Hagen and L. G. Marzilli, Inorg. Chem., 1991, 30, 4673-4676.

118 V. Calvo-Perez, S. Ostrovsky, A. Vega, J. Pelikan, E. Spodine and W. Haase, Inorg. Chem., 2006, 45, 644-649.

119 D. Shi, Z. You, C. Xu, Q. Zhang and H. Zhu, Inorg. Chem. Commun., 2007, 10, 404- 406.

120 Z. Tomkowicz, S. Ostrovsky, H. Mueller-Bunz, A. J. H. Eltmimi, M. Rams, D. A. Brown and W. Haase, Inorg. Chem., 2008, 47, 6956-6963.

121 J. Welby, L. N. Rusere, J. M. Tanski and L. A. Tyler, Inorg. Chim. Acta, 2009, 362, 1405-1411.
122 G. Aromí, A. S. Batsanov, P. Christian, M. Helliwell, A. Parkin, S. Parsons, A. A. Smith, G. A. Timco and R. E. P. Winpenny, Chem.Eur. J., 2003, 9, 5142-5161.

123 M. Ciampolini and I. Bertini, J. Chem. Soc. (A), 1968, 2241.

124 A. B. P. Lever, Inorganic Electronic Spectroscopy, Elsevier, Amsterdam, 1984.

125 O. Kahn, Molecular Magnetism, VCH, New York, 1993.

126 C. J. O'Connor, Prog. Inorg. Chem., 1982, 29, 203.

127 R. L. Carlin, Magnetochemistry, Springer-Verlag, Heidelberg, 1986.

128 P. Comba, M. Kerscher, G. A. Lawrance, B. Martin, H. Wadepohl and S. Wunderlich, Angew. Chem., Int. Ed., 2008, 47, 4740-4743.

129 B. S. Hammes, V. G. Young and A. S. Borovik, Angew. Chem., Int. Ed., 1999, 38, 666-669.

130 M. D. Fryzuk, D. B. Leznoff, R. C. Thompson and S. J. Rettig, J. Am. Chem. Soc., 1998, 120, 10126-10135.

131 B. S. Jaynes, T. Ren, S. C. Liu and S. J. Lippard, J. Am. Chem. Soc., 1992, 114, 9670-9671.

132 T. Yi, C. Ho-Chol, S. Gao and S. Kitagawa, Eur. J. Inorg. Chem., 2006, 1381.

133 R. Boca, Coord. Chem. Rev., 2004, 248, 757-815.

134 A. V. Palii, B. S. Tsukerblat, E. Coronado, J. M. Clemente-Juan and J. J. Borras-Almenar, J. Chem. Phys., 2003, 118, 5566-5581.

135 F. Lloret, M. Julve, J. Cano, R. Ruiz-Garcia and E. Pardo, Inorg. Chim. Acta, 2008, 361, 3432-3445.

136 Y. Shimazaki, R. Kabe, S. Huth, F. Tani, Y. Naruta and O. Yamauchi, Inorg. Chem., 2007, 46, 6083-6090. 